UNITED STATES DEPARTMENT OF THE INTERIOR

Harold L. Ickes, Secretary

GEOLOGICAL SURVEY

W. C. Mendenhall, Director

Water-Supply Paper 796-D

\title{
GEOLOGY AND GROUND-WATER RESOURCES OF OGDEN VALLEY, UTAH
}

BY

R. M. LEGGETTE AND G. H. TAYLOR

Prepared in cooperation with the

CITY OF OGDEN

\author{
- \\ Contributions to the hydrology of the United States, 1937 \\ (Pages 99-161)
}

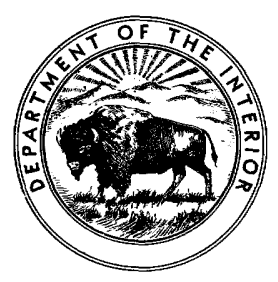

UNITED STATES

GOVERNMENT PRINTING OFFICE

WASHINGTON : 1937 
Abstract........................................ 99

Introduction....................................... 100

Purpose and scope of investigation............................ 100

Location and general features of area.................... 101

History of the use of water.............................. 103

Previous investigations............................. 103

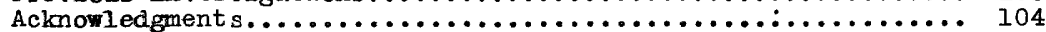

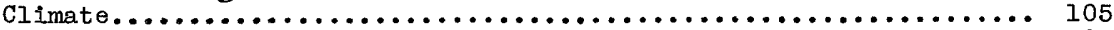

Relief and drainage.............................................. 106

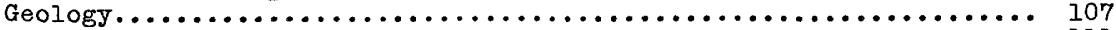

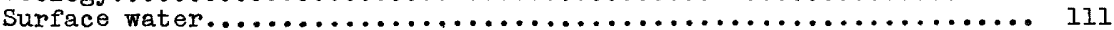

South Fork of ogden River........................ 111

Hunt sville area.............................

Artesian Park near head of Ogden Canyon............. 111

Middle Fork of Ogden River and Huntsville Spring Creek....... 112

Artes1an Park.............................. 112

Vicinity of electric-rail road bridge............... 112

Area north of Hunt sville......................... 112

North Fork of Ogden River at Artesian Park............... 114

Ogden River.................................... 114

Head of 0gden Canyon............................. 114

Gain in flow through ogden Canyon................. 114

Total surface inflow and outflow of ogden valley......... 116

Ground water........................................... 119

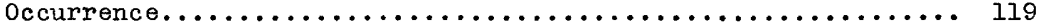

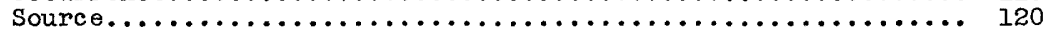

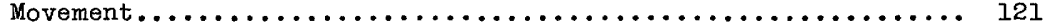

Fluctuations of water level......................... 122

Test wells and continuous records................. 122

Periodic measurements............................ 123

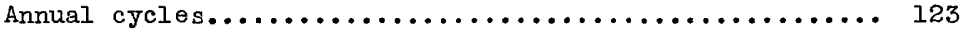

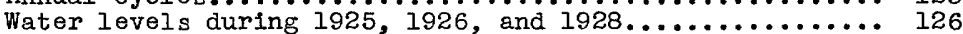

Changes in atmospheric pressure, transpiration by plants,

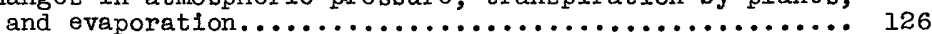

Fluctuations caused by earthquakes................ 128

Comparisons of ground-water levels during 1933, 1934,

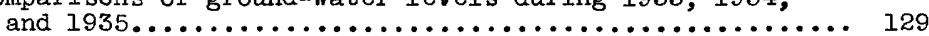

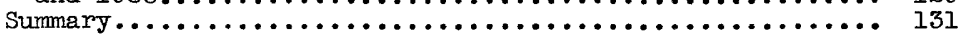

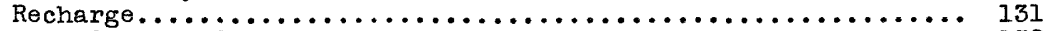

Seepage from streams........................... 132

Penetration of precipitation and irrigation water........ 133

Quantitative estimate............................. 134

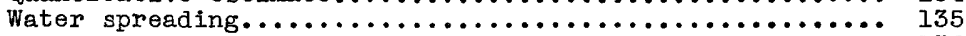

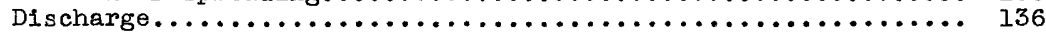

Shallow water body above artesian confining bed........ 136

Recharge area.............................. 137

Artesian reservoir............................... 137

Quantitative estimate.......................... 141

Quality...................................... 142

The Pine view Dam and reservoir............................... 142

General features................................ 142

Probable effects upon the artesian reservoir................ 143

Relation of artesian discharge to stream flow...................... 144

Well records.............................................. 146

\section{ILLUSTRATIONS}

Plate 35. Annual cumulative departure from normal precipitation at Ogden, Utah, and annual precipitation at Ogden, and Huntsville, Utah........................ In pocket 36. Map of part of Ogden Valiey, Weber County, Utah.... In pocket 37. Graphs of flow of South Fork of Ogden River, precipitation at Ogden, withdrawal of ground water at Artesian Park, and water levels in five observation wells in Ogden Valley, $1932-35 . . . \ldots \ldots \ldots \ldots \ldots$. In pocket 
Plate 38. Hydrographs of observation wells in Ogden Valley and

flow of South Fork of ogden River............ In pocket

39. Stream flow in Ogden Valley, $1933-34 \ldots \ldots \ldots \ldots \ldots \ldots$.... In pocket

40. Well logs, Ogden Valley, Utah................. In pocket

Figure 17. Map of Utah and part of Idaho showing areas covered

by ground-water investigations................ 102

18. Average monthly precipitation at Huntsvilie, Utah...... 105

19. Stream flow in ogden Valley, $1925-26 \ldots \ldots \ldots \ldots \ldots \ldots \ldots \ldots$

20. Total surface-water outflow from Ogden Valiey, Utah, $1894,1921,1925,1928,1932,1933$, and 1934....... 115

21. Diagrammatic sketch of an ideal east-west section through Ogden Valley, Utah, showing ground-water con-

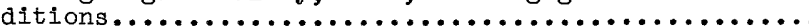

22. Profiles between Artesian Park and weil $\dddot{\eta}$, Ogden Valley, Utah, showing land surface and levels at which water stood in wells on May 31, 1933, and octo-

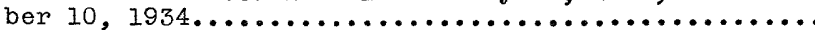

23. Discharge from weils at Artesian Park and water levels

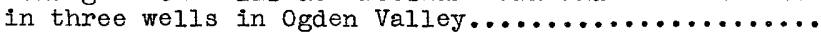

24. Hydrographs of streams and wells in ogden Valiey, Utah, showing effects of plant transpiration on water

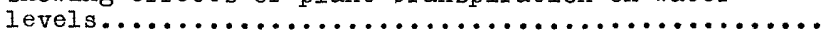

25. Hydrograph of weli $8 i$ and graph of fiuctuation of atmospheric pressure in Ogden Valley, Utah, showing barometric type of water-level fluctuation...........

26. Hydrographs of five wells in ogden Valley, Utah, showing fluctuations of water levels in welis caused by

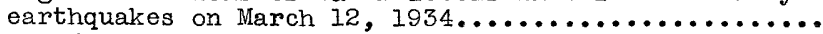

27. Graph from recording pressure gage operating on a ij3foot artesian well in Ogden Valley, Utah, showing effect of earthquake of March $12,1934 \ldots \ldots \ldots \ldots \ldots \ldots \ldots$ 
Ogden Valley is a fault trough bounded on both the east and west by faults that dip toward the middle of the valley. This fault trough contains unconsolidated deposits of clay, sand, and gravel, whose thickness is more than 600 feet. These materials are stream and lake deposits and in places are well sorted and stratified. The lake sediments were laid down in a small lake that occupied Ogden Valley and that was connected with glacial Lake Bonneville at its high stage by an arm of water that occupied Ogden Canyon. During this stage of Lake Bonneville the Ogden Valley was completely filled with lake sediments up to an altitude of about 4,900 feet. These sediments include about 70 feet of clay, sand, and gravel in alternating layers, below which is a bed of varved clay whose maximum thickness is about 70 feet. This clay is continuous under the lower parts of the valley and is the confining bed that produces the artesian conditions. Below the varved clay is a deposit of silt, 3 and, and gravel of unknown thickness, most of which is believed to be preBonneville alluvium.

In most summers the streams entering Ogden Valley are diverted for irrigation, and the upper parts of their channels are generally dry during the irrigation season. Lower down in the valley seepage water appears in the channels, and below these points there is continuous flow. The flow of the Ogden River increases as it passes through Ogden Canyon. This gain in flow is believed to be derived chiefly from ground-water seepage from the canyon walls, although there is probably some groundwater underflow from Ogden Valley at the head of Ogden Canyon. Some of the gain is also due to leakage from pipe lines in the canyon.

of the 146 wells whose records are given in this report, 70 are flowing wells.

Ground water in Ogden Valley occurs in the pore spaces of the gravel, sand, and clay. of the valley fill. Wells drilled through the clay confining bed encounter water that is under artesian pressure. Shallow wells that do not pass through the clay, or wells in the higher parts of the valley, where the clay is absent, encounter water-table conditions in which the water is not confined under pressure. The ground water in the valley moves approximately paraliel to the general slope of the land surface. The ground water in the recharge area--that is, the higher parts of the valley, where the clay confining bed is absent--moves down gradient toward the upper edge of the clay confining bed, where it either enters the artesian reservoir or becomes a part of the shallow ground-water body above the confining bed.

The records of measurements of ground-water levels show that the water levels fluctuate in annual cycles, the amplitudes of which range from 2 feet to 30 feet or more. The highest water levels occur during April, May, or June of each year, and the lowest water levels usually occur in the later part of the winter. The withdrawal of water at Artesian Park probably affects artesian pressures in the entire artesian reservoir and, possibly, to some extent the water table in the recharge area. Miscelíaneous meásurements of artesian pressure at Artesian Park in 1925, 1926, and 1928 compared with measurements made in 1933 seem to indicate that although the pressure was greater in 1933, the difference was probably not large. Instrumental records show that water levels in ogden Valley fluctuate in response to changes in atmospheric pressure, transpiration by plants, evaporation, and earthquakes. The groundwater levels before the period of spring recharge were about the same in 1935 as in 1933, notwithstanding the drought and the heavy withdrawals in 1934. 
Ground-water recharge takes place by penetration of water that falls as rain or snow on the valley, by seepage of excess irrigation water, and by seepage of water from stream channels and irrigation canals. The water that sinks to the water table in the area above the clay confining bed does not reach the artesian reservoir because the clay of the confining bed is essentially impervious, as shown by laboratory tests. Seepage from streams is probably the major source of ground-water recharge. It is estimated that during the recharge period from November 1932 to June 1933 the ground-water recharge amounted to about 23,000 acre-feet. Ground-water recharge can probably be increased by applying stream flood waters to the recharge area and thus placing in ground storage water that otherwise may be wasted.

Natural discharge of ground water from the valley occurs chiefly as flow from springs, return flow to streams, transpiration by plants, and evaporation from soll. Artificial discharge occurs by the withdrawal of water from flowing and nonflowing wells. The greater part of the artificial discharge of water from the artesian reservoir occurs in Artesian Park, where there are 48 wells connected to the municipal water system of the city of Ogden. During 1933 and 1934 the discharge from these wells ranged from about 12.9 to 20.5 second-feet. It is estimated that during the year ending september 30, 1934, the total ground-water discharge from Ogden Valley was about 27,700 acre-feet.

The waters of Ogden Valley are satisfactory for domestic use and most industrial uses, but some of them are harder than is desirable for certain purposes. The fluoride content of samples of water from seven wells was determined, and it was found that these waters are nat likely to be objectionable on account of their fluoride content.

The Pine View Dam, which is now under construction by the United States Bureau of Reclamation, will impound about 30 to 40 feet of water over a part of the artesian reservolr. Although the additianal load of surface water above the artesian confining bed will tend to increase artesian pressures and the discharge from artesian wells, it is believed that the change will not be of great practical importance.

The utilization of the artesian reservoir has inevitably resulted in a somewhat greater seasonal lowering of water levels than would otherwise have occurred. The stream flow derived from seepage has therefore also been diminished. During the winter and spring of any Jear ground-water recharge has been increased over what it would otherwise have been, partly because of lower water levels at the beginning of the recharge period and partly because of the withdrawal of water from artesian wells during the period. During wet years, in spite of the artesian development, water levels at the end of the recharge period are probably nearly as high as they would have been had there been no artesian development, but in dry years the difference has doubtless been greater. In the future, unless there should be heavy pumping from wells in the recharge area the artesian water supply will be perennially adequate for at least the present rate of withdrawal. Moreover, somewhat greater utilization of the artesian reservoir would be possible by increasing the draft at times when the water is most needed, thus inducing greater ground-water recharge at times of surplus water.

INTRODUCTION

Purpose and scope of investigation

On June 15, 1932, the city of Ogden and the United States Geological Survey entered into an agreement for the purpose of investigating ground-water conditions in Ogden Valley and their relation to the stream flow in the valley. The city of ogden obtains all but a small part of its municipal water supply from a group of artesian wells in Ogden Valley, and these withdrawals constitute the greater part of the water 
the heavy spring run-off, is diverted for irrigation, and the summer flow is generally inadequate to supply all demands. The city of Ogden contributed $\$ 8,000$ and the Federal Government contributed $\$ 4,000$ toward the investigation.

Field work was carried on during the summer and fall of 1932 by R. M. Leggette and L. K. Wenzel, during the summer and fall of 1933 by R. M. Leggette, and during the fall of 1934 by G. H. Taylor, all under the supervision of O. E. Meinzer, geologist in charge of the division of ground water, United States Geological Survey. In September 1932 several automatic water-level recorders were installed on observation wells, and when Messrs. Leggette and Wenzel were not in the field these were read weekly by G. H. Taylor, who was assisted by H. E. Northrup during the first half of 1933. After November 1934 C. L. Coray, Ogden city engineer, and Thomas Curtis, of the United States Bureau of Reclamation, were in charge of five of these recorders.

Location and general features of area

Ogden Valley is in Weber County, Utah, on the east side of the most westerly range of the Wasatch Mountains, about 12 miles east of the city of Ogden ( $f 1 g .17$ ) and lies within the Great Basin. During a part of the glacial epoch the valley was occupied by a lake that was connected with the main Lake Bonneville by an arm of rater occupying the Ogden Canyon. The valley has an area of about 23 square miles and is completely surrounded by mountains, some of which rise to altitudes of about 10,000 feet. The only outlet for the water in the valley is through Ogden Canyon, a narrow gorge cut through the Wasatch Mountains to the west of the valley. For the purpose of this report Ogden Valley is considered to be the flatter part of the valley, which lies below the foot of the surrounding mountains at altitudes of 4,800 to 5,000 feet or more.

The main occupation of the inhabitants of the valley is stock raising and farming. The water for irrigation is diverted from the three main tributaries of the Ogden River and from numerous smaller spring-fed streams entering the villey from the surrounding mountains. Nearly all of the surface water entering the valley during the summer is diverted for irrigation. Most of the water that appears in the tributary streams as returm flow from the valley and the water that is gained by the Ogden River as it passes through the Ogden Canyon is used 


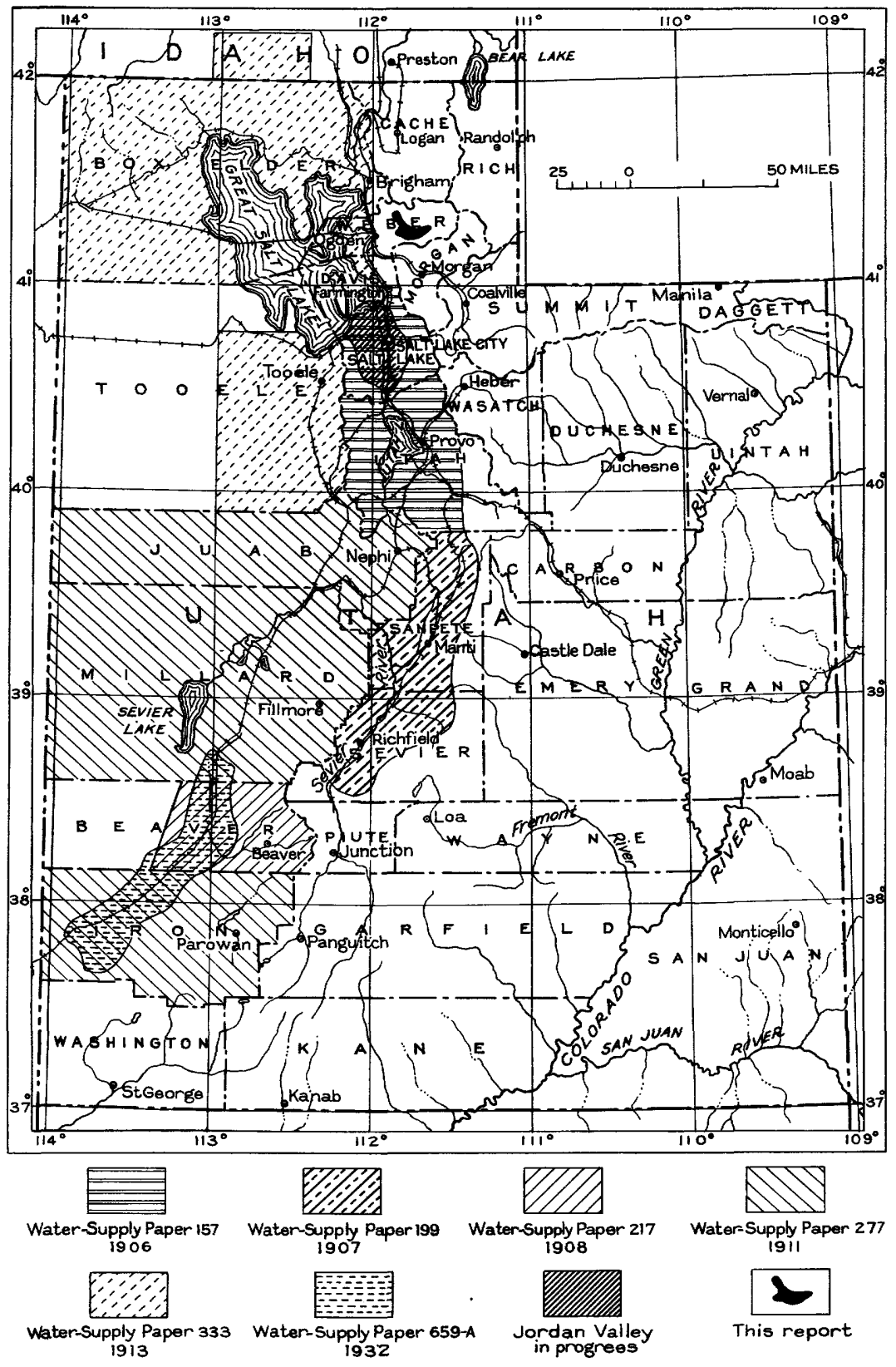

Figure 17.--Map of Utah and part of Idaho showing areas covered by ground-water investigations. 
for irrigation in the area west of the Wasatch Mountains in the vicinity of Ogden. The population of Ogden Valley in 1930 was 1,367, of whom 520 lived in the town of Huntsville.

\section{History of the use of water}

Ogden Valley was settled a few years after the first pioneers arrived in Utah in 1847. Before the valley was settled, however, the inhabitants in the vicinity of the city of Ogden began to irrigate with water from the Ogden River below the mouth of the canyon, and the group of people who use water from this source are at present known as the lower-valley water users. Later the settlers in Ogden valley claimed water rights on the three branches of the Ogden River in Ogden Valley, and this group is known as the upper-valley water users. During 1914 the city of Ogden began developing artesian water near the junction of the three branches of the river in Ogden Valley, and the drilling of wells by the city continued at irregular intervals until 1933. During the summer and fall of most years the flow of the Ogden River consists partly of ground water returned to its tributaries from the sediments in Ogden Valley and partly of water that seeps into its channel as the river passes through Ogden Canyon. Conflicts among the three groups interested in the water resources of Ogden Valley arose, and in July 1929 an agreement was made which provided that during a 7-year period all litigation would be suspended and the conditions and use of water would remain undisturbed pending investigation of the source, disposal, and relation of the waters of the valley.

\section{Previous investigations}

Prior to the investigation described in this report, very few data regarding the ground-water conditions in Ogden Valley had been obtained. In 1894 Samuel Fortier, of the experiment station of the Agricultural College of Utah, made an investigation of the seepage water and underflow of rivers in parts of the state, and this included a detailed study in Ogden Valley. No measurements of ground-water levels were made, but an intimate relation between the ground water and the surface waters was recognized.

1 Fortier, Samuel, Preliminary report on seepage water and the underflow of rivers: Utah Agr. Coll. Exper. Sta. Bull. 38, February 1895; Seepage water of northern Utah: U. S. GeoI. Survey Water-Supply 
In $1921 \mathrm{~J}$. J. Sanford, of the office of the State engineer, made another hydrologic study of ogden Valley, during which only the flow of the streams in the valley was considered.

The controversies over the water rights in the valley resulted in an investigation of the stream flow and precipitation and related factors by the office of the state engineer in $1925 .^{2 /}$ This investigation was continued in 1926 and included the determination of the artesian pressure in a few of the flowing wells owned by the city of ogden. Artesian pressures in the same wells were again measured by the office of the State engineer in 1928.

In 1930 test holes were put down near the head of ogden Canyon by the United States Bureau of Reclamation to investigate the site of the Pine View Dam, and the results of these borings were of considerable aid in the geologic interpretations given in this report.

\section{Acknowledgments}

Grateful acknowledgment is made to Ora Bundy and Harman w. Peery, mayors of the city of Ogden, to Fred Williams, city commissioner of water supply, and to J. C. Brown and C. L. Coray, city engineers, during whose terms of office the investigation was made, for their helpful cooperation; to Harry Irwin, city superintendent of waterworks, for helpful cooperation in field work; to E. O. Larson, J. R. Iakisch, and Thomas Curtis, of the United States Bureau of Reclamation, for cooperation in making avallable data collected by them and for continuing observations of the ground-water levels in the valley. George Bacon, State engineer, made avallable the data gathered by his office in Ogden Valley. H. M. Ritter, I. K. Peterson, and W. H. Burrows, residents of Ogden Valley, cooperated in the use of their lands for testwell sites, and all the residents of the valley aided by suppiying information and giving permission to prosecute the investigation on their lands. Acknowledgment is also due to J. C. Alter, of the United States Weather Bureau, for the loan of climatologic Instruments; to A. B. Purton, of the United States Geological Survey, for cooperation in obtaining stream-flow data and for other assistance; and to Ralf R. Woolley, of the United States Geological Survey, for his personal interest and valuable help. 


\section{CLIMATE}

The climate of Ogden Valley is typical of the semiarid West at similar altitudes. The summers are relatively short, and temperatures are moderate. Unofficial temperatures of about 450 below zero were reported during December 1932, and temperatures of $20^{\circ}-30^{\circ}$ below zero are rather common. Normally the valley floor is covered with 2 to 4 feet of snow at some time during the winter, but during the winter of 1933-34 very little snow fell in the valley. The annual precipitation during the years 1933 and 1934 was not excessively below normal at Ogden, but a serious shortage of water existed during the summer of 1934 because of the Ilght snowfall at higher altitudes during the preceding winter.

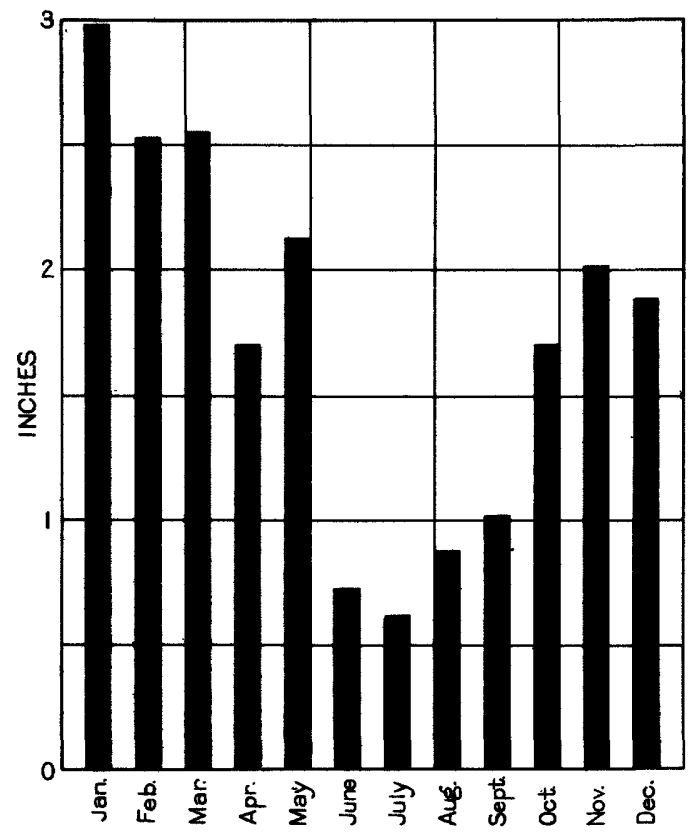

Figure 18.--Average monthly precipitation at Huntsville, Utah.

Complete records of precipitation in Ogden Valley have not regularly been kept, but there are available complete records of annual precipitation at Huntsville for 20 different jears between 1895 and 1927. The annual precipitation during these 20 years ranged from 14.73 inches in 1919 to 36.25 inches in 1909, and the average was 20.86 inches. 
The average monthly precipitation ranged from 0.62 inch for July to 2.98 inches for January. The average monthly precipitation at Huntsville is shown in figure 18. Available long-time records of precipitation nearest to Ogden Valley are those for Ogden. The average annual precipitation at Ogden during the 20 years for which records are available at Huntsville was about 4 inches less than at Huntsville. The annual precipitation at Ogden for the period 1870 to 1934, inclusive, is shown in plate 35 (in pocket), together with the available records from Huntsville. Plate 35 also shows the accumulative anmual departure from the normal precipitation at Ogden, from which may be deduced an approximation of the general trend of annual precipitation in Ogden Valley. The downward trend of the accumulative departure curve between 1870 and 1903 shows that the precipitation was consistently below normal during that period, and the upward trend between 1904 and 1930 shows that it was consistently above normal. The precipitation from 1930 to 1933 was below normal, the cumulative deficiency for 1930-34 amounting to 6 inches at Ogden.

\section{REUIEF AND DRAINAGE}

Ogden Valley is a high valley entirely surrounded by mountains and has only one drainage outlet. The main drainage channels of the valley are the North, Middle, and South Forks of the Ogden River, which converge near the west side of the valley just before the river enters the steep, narrow, and rocky Ogden Canyon. Of the three major streams the South Fork contributes the greatest amount of water to Ogden Valley and the Middle Fork the least. Several smaller creeks enter the valley from the surrounding mountains and contribute a considerable amount of water during the spring. Only two or three of these smaller creeks carry an appreciable amount of water during the summer, and all of this is diverted for irrigation within the valley. A few springs that emerge along the foot of the mountains flow throughout the year. The largest are the Patio Spring, which supplies a swiming pool and small sumer recreation park, and two or three springs at the head of Liberty Spring Creek. Springs that rise from the valley floor at an altitude of about 4,925 feet constitute the main source of fhutsville spring Creek, which flows the entire year. The mountains surrounding the valley have steep slopes and sustain varying amounts of vegetation in the form of underbmish and small trees. The valley floor slopes more or less regularly 
from the north, northeast, and east toward the head of Ogden Canyon. The valley floor has the form of a bench into which the three main tributaries of the Ogden River have cut their small valleys. Near the head of Ogden Canyon the channels of the three tributaries 11e about 80 feet below the general benchlike floor of the valley, but farther upstream this distance becomes less and less until in the upper parts of the valley the channels are only a few feet below the valley floor. Just north of funtsville a hill composed mainly of gravel and cobbles rises about 70 feet above the valley floor.

\section{GEOLOGY}

Certain features of the geology of Ogden Valley have been described by Gilbert and by Blackwelder. They considered mainly the physiographic history of the valley and the structure and nature of the bedrock surrounding the valley. These phases of the geology have direct bearing on the present ground-water investigation, but they are less important than the geology of the unconsolidated sediments that underlie the valley floor. For this reason these sediments were studied in considerable detail during the present investigation.

Ogden Valley is a fault trough bounded on the east and west by faults that dip toward the center of the valley. (See fig. 2l.) The fault trough was formed long before the glacial epoch, which, as pointed out below, profoundly affected the geologic conditions that in great measure determine the occurrence of ground water in the valley. In this fault trough was deposited a great thickness of clay, silt, sand, and grave1. The total thickness of this material is not known, but one well (no. 46) near the head of Ogden Canyon penetrated 600 feet without encountering bedrock. These sediments are chiefly stream and lake deposits. Their deposition covered a long period and was more rapid at certain times than at others. The events that resulted in the filling of the lower part of the fault trough are not known in detail, but it is probable that there were dry periods when alluvium was deposited by streams entering the valley during occasional storms. Other periods were more humid, and at such times the valley probably contained a small lake in which sediments were deposited. 
The top 100 feet or so of the valley filling was deposited in an ancient lake that at its highest stage stood about 400 feet higher than the lowest part of the present valley. This lake was connected with the large ancient Lake Bonneville by an arm of water occupying Ogden Canyon. Lake Bonneville occupled the area lying west of the Wasatch Mountains. According to Gilbert its history is briefly as follows:

In the early part of the glacial epoch a lake was formed in the Bonneville Basin. This lake rose within about 90 feet of an overflow point at Red Rock Pass, at the north end of Cache Valley, in southern Idaho. The lake then receded until its area was probably less than that of the present Great Salt Lake. The lake again began to rise, and this time it reached the level of the divide at Red Rock Pass and overflowed. This highest stage of the lake is known as the Bonneville stage, and its level was about 1,000 feet above the present Great Salt Lake. The divide at Red Rock Pass consisted of about 400 feet of alluvium resting on bedrock. The alluvial divide was rapidly cut down, and for a long time the lake overflowed the bedrock divide. This stage of the lake is known as the Provo stage, and Its level was about 600 feet above the level of the present Great Salt Lake. Later the lake began to recede and its overflow ceased. The present Great Salt Lake is but a low stage of the glacial Lake Bonneville. The rise and fall of the level of Lake Bonneville was no doubt oscillatory, any one major rise being the net result of numerous fluctuations of stage.

During the Bonneville stage of the glaclal lake Ogden Valley was completely filled with lake sediments as high as about 4,900 feet above sea level. This level is only approximate, for the surface of this filling slopes toward the head of ogden Canyon. It is referred to in this report as the 4,900-foot bench merely for convenience. The Provo level of Lake Bonneville was about 4,800 feet above sea level, and these lake sediments therefore could not have been deposited during the Provo stage. In many places these sediments contain oscillation ripple marks, typical lake clays, and other features which clearly show that they were deposited in a lake. The following section is typical of these lake sediments : 
Section of exposure and auger hole in center $\mathrm{N}_{\frac{2}{2}}$ sec. 14, T. 6 N., R. 1 E., Ogden Valley

\begin{tabular}{|c|c|c|}
\hline & $\underset{\text { (feet) }}{\text { Thickness }}$ & $\begin{array}{l}\text { Depth } \\
\text { (feet) }\end{array}$ \\
\hline 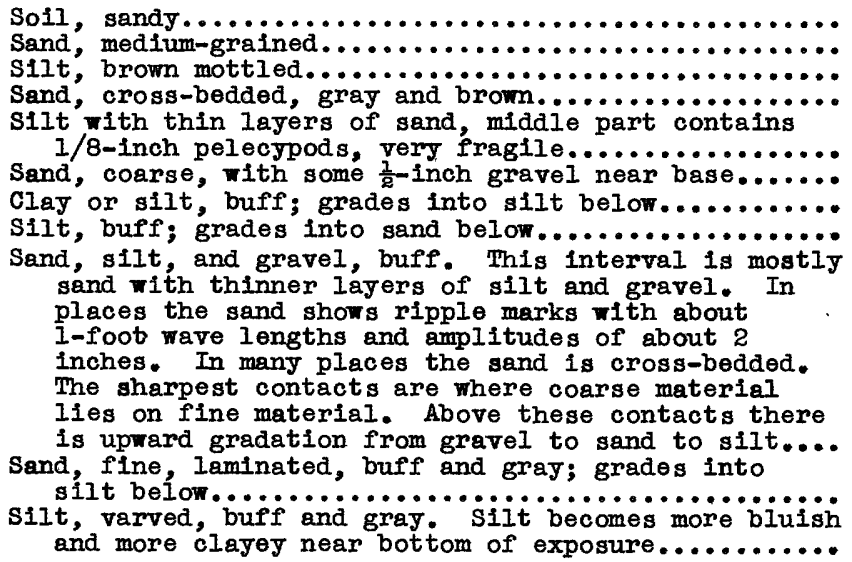 & $\begin{array}{l}4 \\
\frac{1}{2} \\
2 \frac{1}{2} \\
1 \frac{1}{2} \\
3 \\
2 \frac{1}{2} \\
1 \frac{1}{2} \\
1 \frac{1}{2}\end{array}$ & $\begin{array}{l}11 \frac{1}{2} \\
14 \\
15 \frac{1}{2} \\
17\end{array}$ \\
\hline $\begin{array}{l}\text { Stream level, about } 4,830 \text { feet above sea level. Pot- } \\
\text { holes occur in the varved clay from about } 2 \text { feet } \\
\text { above stream level to } 4 \text { feet below stream level. } \\
\text { Section continued below stream level in } 4 \text {-inch } \\
\text { auger hole. }\end{array}$ & & \\
\hline 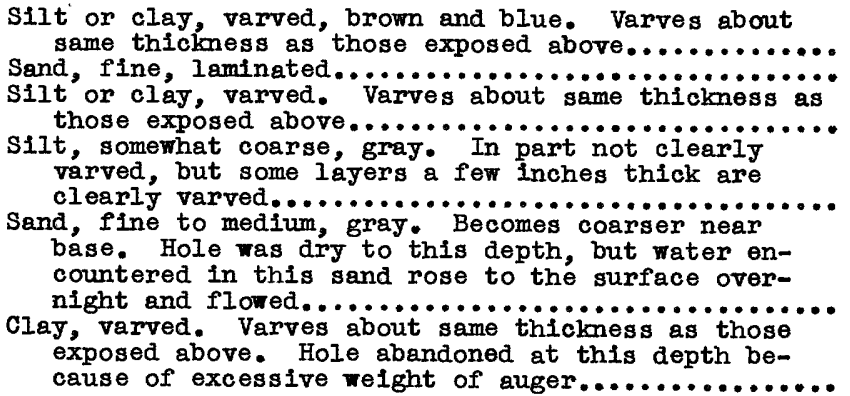 & $\begin{array}{l}8 \\
1\end{array}$ & $110 \frac{1}{8}$ \\
\hline
\end{tabular}

The silt and clay from a depth of 69 to 122 feet in the above section was not completely penetrated by the auger hole. However, four test holes (wells 81, 82, 101, and 102) passed through this clay bed. Wells 101 and 102 were drilled in the valley of the Middle Fork, which has been cut down into this clay bed. By leveling to these test wells from the approximate top of this clay bed exposed nearby in the bank of the Middle Fork a thickmess of about 70 feet for the clay bed was determined. This bed of clay is exposed in numerous parts of the valley and was studied in detail, both in the natural exposures and in several auger holes. Undisturbed block samples of the clay were collected and 
The clay consists of alternating thin layers of densè, sticky, puttylike clay and silt, usually grayish blue and brown. The uniform thickness and continuity of the individual layers in any one exposure is very striking. The clay is believed to be a varved clay that was deposited in the quiet waters of the lake that occupied Ogden Valley durIng the highest stage of Lake Bonneville. Each pair of layers constitutes a varve and represents the summer and winter deposition of one year. An approximate count of the varves indicates that alout 25,000 years is represented by the total thickness of the clay bed.

The nature of the clay, its mode of deposition, and its known areal distribution all point to the fact that it underlies continuously the area represented in plate 36 (In pocket) to the southwest of the dashed line, which shows the approximate upper edge of the clay bed. This clay bed is of great importance in connection with the ground water in ogden Valley, because it is the confining bed that produces the artesian conditions.

The general nature of the sediments overlying the clay bed is shown in the section given above. There are no major breaks of deposition othex than numerous nongradational contacts where the coarser material. lies on the finer material. In numerous exposures of the sediments that overlie the clay bed, oscillation ripple marks were observed only a short distance below the top of the 4,900-foot bench. The gravel, sand, and clay that overlie the clay bed are belleved to have been deposited in the lake that occupied Ogden Valley during the later part of the Bonneville stage of Lake Bonneville.

The nature of the sediments that underlie the clay bed is shown in a general way by the well logs in plate 40 . The wells were drilled over a period of years by different well drillers, and the terms used by them in describing the materials penetrated are probably not uniform. A correlation of the well logs was therefore not feasible. It is believed that most of the material underlying the clay bed is irregular and lenticular. The sand and gravel immediately below the clay bed was probably deposited during the early part of the Bonneville stage, before the lake had risen to its highest level. The material of greater depths is probably mostly pre-Bonneville alluvium. 


\section{SURFACE WATER}

\section{South Fork of Ogden River}

Huntsville area.--Continuous records of stream flow of the South Fork of the Ogden River have been obtained by the United States Geological Survey since 1921 at a point a short distance above the mouth of South Fork Canyon and above all irrigation diversions. (See pl. 36.) The stream flow at this station for the period october 1932 to September 1934 is shown graphically in plates 37 and 38 (in pocket). The maximum dally flow during this period was 816 second-feet, and the minimum was 22 second-feet. The maximum dally flow during the year ending September 30, 1934, was 89 second-feet, and this was about one-fifth to one-tenth the amount normally expected during the annual spring run-off, the result of scant precipitation at higher altitudes during the winter of 1933-34. At no time during 1934 was there a continuous flow through the entire channel of the South Fork of the Ogden River in Ogden Valley. During part of the winter there was practically no diversion of water from the South Fork where it enters Ogden Valley, and thus there was channel-seepage loss of the entire flow of the stream, amounting to about 35 or 40 second-feet.

Artesian Park near head of Ogden Canyon.--During part of 1925 and 1926 a stream-gaging station was maintained on the South Fork of the Ogden River near Artesian Park, a short distance above the junction of the three forks of the ogden River. (See pl. 36.) This station was again operated for a short period in 1933 and for a longer period in 1934. The flow of the South Fork during these periods is shown graphically in figure 19 and plate 39 (in pocket). It is probable that during the summers of 1925 and 1926 the flow past this station was mostly ground-water run-off, or seepage into the stream channel, for no doubt most of the flow of the South Fork was either diverted before it entered the valley or seeped from the channel soon after it entered the valley. All the flow past the station measured during 1933 and 1934 was ground-water run-off, because at no time during this perlod was the flow in the channel of the South Fork continuous through the valley.

6/ Grover, N. C., and others, Surface water supply of the United States, 1926, pt. 10, The Great Basin: U. S. Geol. Survey Water-Supply Paper 630, pp. 41-42, 1930 . 
Middle Fork of Ogden River and Huntsville Spring Creek

Artesian Park.--No continuous measurements of the flow of the Middle Fork of the Ogden River are avallable except for short periods. Records are avallable for the period June 22, 1925, to october 20, 1926, but they include the flow of both Huntsville Spring Creek and the Middle Fork of the Ogden River. These records are shown graphically in figure 19. Although there was probably some inflow of surplus irrigation water, the amount was probably small, and the discharge during the summer was no doubt nearly all ground-water mun-off. During the summer a small irrigation ditch diverted as much as about 4.4 second-feet above the point of measurement. However, the average diversion by this ditch was about 3.6 and 0.6 second-feet for a part of June and September 1928 , respectively, and 1.5 and 1.2 second-feet during July and August 1925, respectively. $8 /$

Vicinity of electric-railroad bridge.-The flow of the Middle Fork of the Ogden River measured just above its junction with Huntsville Spring Creek at the bridge on the electric railroad for the period August 11, 1933, to November 16, 1934, is shown in plate 39. With the exception of the period from about March 5 to about May 15, 1934, when there was continuous flow throughout the channel, the flow was mostly ground-water run-off, although it is probable that in the early part of the irrigation season a small amount was surplus irrigation water.

Area north of Huntsville.--The flow of Huntsville Spring Creek at a point just north of Huntsville from August 11, 1933, to November 16, 1934, is also shom in plate 39. During 1933 and 1934 the irrigation ditch mentioned above was diverting water just below the point of measurement on Huntsville Spring Creek. The amount of this diversion was probably about the same or less than during 1925. The flow of Huntsville Spring Greek during 1933-34 was nearly all ground-water runoff, probably only a small amount being surplus irrigation water and local surface run-off.

7/ Grover, N. C., and others, op. cit., pp. 43-44.

8) Unpublished data from the Utah State engineer's report on Ogden Valley, 1925 and 1928. 


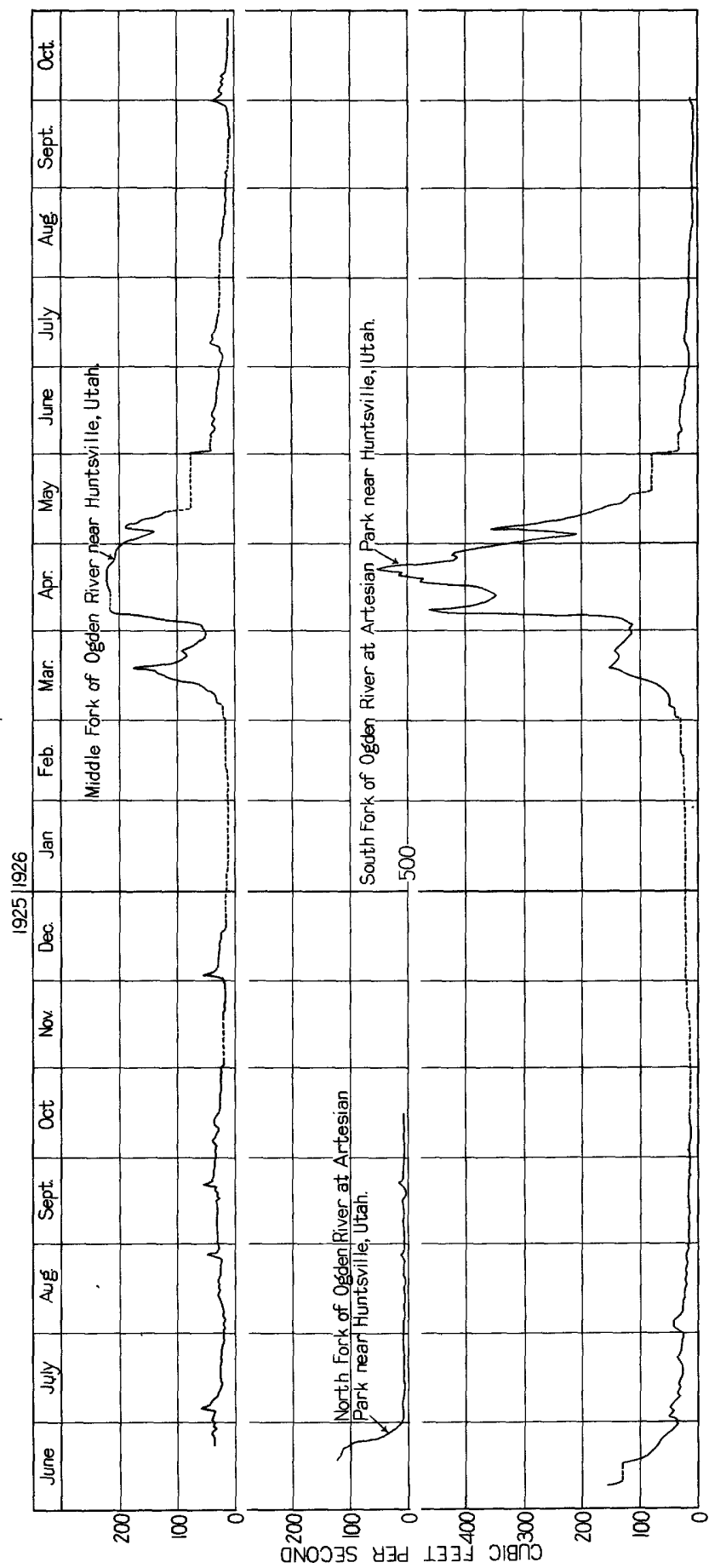

Figure 19.--Stream flow in Ogden Valley, 1925-26. 
North Fork of Ogden River at Artesian Park

The flow of the North Fork of the Ogden River at Artesian Park for the period June 17, 1925, to October 15, 1925, is shown by figure 19. After about July 5, 1925, the flow of this stream was probably all ground-water mun-off, although a very small part may have been surplus irrigation water. The flow of the North Fork for the period August 11 , 1933, to November 16, 1934, measured at weekly intervals, is shown in plate 39. Except in the period from about March 5 to April 15, 1934, the flow is ground-water mun off from areas within Ogden Valley. It is not probable that any of the flow was surplus irrigation water, because of the shortage of rater during 1934, although there may have been a small amount of local surface run-off during the spring.

Ogden River

Head of Ogden Cenyon.--Continuous records of the total stream flow from Ogden Valley are avallable, but for the purpose of this report only the flow during the summer and early fall are significant in relation to ground-water discharge. Plate 39 shows the total flow of the ogden River at the Ploneer Dam, near the head of Ogden Canyon, for the period August 1, 1932, to september 30, 1934. This station is about $1 \frac{1}{2}$ miles below the junction of the three forks of the ogden River. The total flow of the three forks, as measured above their junction at intervals of about one week, is shown for the same period. The difference between the two curves is probably due to inflow or evaporation and transpiration between the points of measurement. The total flow from August to November, 1933, and from July to October, 1934, was practically all ground-water mun-off, with only a very small amount, if any, of surplus irrigation water. Records of the total stream flow from Ogden Valley are available for the months of July, August, and September in each of the six years 1894, 1925, 1928, 1932, 1933, and 1934. These, together with measurements in August and September, 1921, are shown graphically in figure 20 .

Gain in flow through Ogden Canyon.--The Ogden River gains in flow between its entrance into Ogden Canyon and the mouth of the canyon, near the city of Ogden. During certain seasons of the year part of 
this gain is surface water discharged by several small streams tributary to the canyon, but in the summer these small streams carry no water except during local storms. Thus, the summer gain consists essentially of flow from springs or seepage in and near the channel of the river, although some of the seepage, or return flow, probably results from leakage in the pipe lines of the Utah Power \& Light Co. and of the city of Ogden. The average gain in flow between the Ploneer Dam and the mouth of the canyon was measured in 1925 and 1928 by the State engineer.

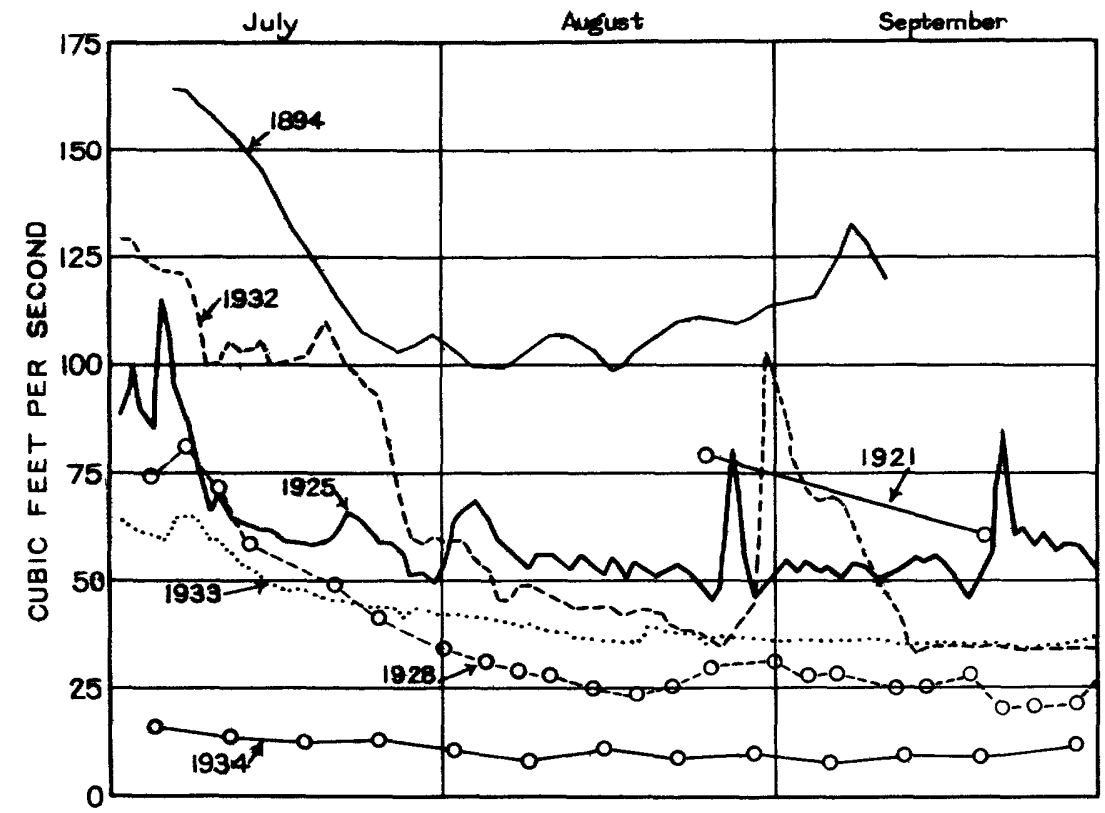

Figure 20.--Total surface-water outflow from Ogden Valley, Utah, $1894,1921,1925,1928,1932,1933$, and 1936.

The average gain during July and August, 1925, was 20 and 16 secondfeet, respectively. During the first 22 days of september 1925 the average gain was 21 second-feet. During July, Auguat, September, and October, 1928, the gain in flow was 18, 19, 18, and 17 second-feet, respectively. The records of flow during 1925 were continuous over the period covered. During 1928 between 8 and 11 measurements a month were made at more or less regular intervals. On August 12, 1933, a flow of 28.5 second-feet was measured at the mouth of Ogden Canyon. On the same day the flow just below Pioneer Dam was only 0.3 second-foot. 
Thus there was a gain in flow of about 28 second-feet in the Ogden River between the head and the mouth of the canyon. Results of measurements of the flow of the Ogden River made at six points in ogden Canyon on September 20, 1934, are show in the following table.

Results of measurements of stream flow made in Ogden Canyon September 20, 1934

\begin{tabular}{|c|c|c|c|}
\hline Location & $\begin{array}{l}\text { Distance } \\
\text { downstream } \\
\text { from } \\
\text { Pioneer Dam } \\
\text { (miles) }\end{array}$ & $\begin{array}{l}\text { Flow } \\
\text { (second- } \\
\text { feet) }\end{array}$ & $\begin{array}{l}\text { Gain per mile of } \\
\text { channel between } \\
\text { successive points } \\
\text { of measurement } \\
\text { ( second-feet) }\end{array}$ \\
\hline & 0 & 0.3 & \\
\hline $\begin{array}{l}700 \text { feet east of west line of } \\
\text { sec. } 16, \text { T. }^{2} \mathrm{~N}, \mathrm{R}_{\bullet} \mathrm{l} \mathrm{E} \text {. }\end{array}$ & 0.3 & 0 & Loss \\
\hline $\begin{array}{l}2,600 \text { feet east of west line } \\
\text { of sec. } 17, T .6 \text { N., R. I E. }\end{array}$ & .9 & 3.8 & 6.3 \\
\hline $\begin{array}{l}1,000 \text { feet west of east line } \\
\text { of sec. } 18, \text { T. } 6 \text { N., R. I E. }\end{array}$ & 1.8 & 5.8 & 2.2 \\
\hline $\begin{array}{l}2,000 \text { feet west of east line } \\
\text { of sec. } 24, T_{.} 6 \text { N., R. I E. }\end{array}$ & 3.1 & 10.9 & 3.9 \\
\hline Mouth of Ogden Canyon & 5.1 & 14.3 & 1.7 \\
\hline
\end{tabular}

The average gain in flow of the river as it passed through the Ogden Canyon was about 2.8 second-feet per mile of channel. Although the gain was greatest in the first mile below Pioneer Dam, the gain farther downstream indicates that a considerable part of the total gain is derived from ground water discharging from the bedrock canyon walls and that the underflow of ground water from Ogden Valley is relatively small.

Total surface inflow and outflow of Ogden Valley.--Measurements of the total surface inflow and outflow of Ogden Valley have been made by various persons or organizations at several times during the past. During the first two weeks in September 1934 the inflow and outflow of the entire valley were again measured. A summary of the available data is given in the following table: 
Total surface inflow and outflow, in second-feet, of Ogden Valley, Utah, on approximately corresponding dates of different years

\begin{tabular}{|c|c|c|c|c|c|c|c|c|c|}
\hline & \multicolumn{3}{|c|}{1894} & \multicolumn{2}{|c|}{1921} & \multicolumn{2}{|c|}{1925} & \multirow{2}{*}{ 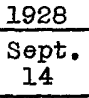 } & \multirow{2}{*}{$\frac{1934}{\text { Sept. }}=$} \\
\hline & $\underset{7-11}{J u 1 y}$ & $\begin{array}{l}\text { Aug. } \\
16-18\end{array}$ & $\begin{array}{c}\text { Sept. } \\
10\end{array}$ & $\begin{array}{l}\text { Aug. } \\
23-26\end{array}$ & $\begin{array}{l}\text { Sept } \\
19-20\end{array}$ & Aug. & $\begin{array}{c}\text { Sept. } \\
15\end{array}$ & & \\
\hline $\begin{array}{l}\text { Inflow above } \\
\text { Irrigated } \\
\text { land }\end{array}$ & 160 & 80 & 79 & 79 & 73 & 59 & 63 & 54 & 30 \\
\hline $\begin{array}{l}\text { Inflow below } \\
\text { irrigated } \\
\text { land }\end{array}$ & & & & 37 & 40 & 34 & 42 & & 2 \\
\hline $\begin{array}{l}\text { Irrigation } \\
\text { diversions }\end{array}$ & 143 & 71 & $27(?)$ & 110 & 78 & 91 & 88 & & 28 \\
\hline $\begin{array}{l}\text { Outflow at } \\
\text { head of } \\
\text { Ogden Canyo }\end{array}$ & 159 & 101 & 119 & 79 & 60 & 46 & 57 & 25 & 9.5 \\
\hline
\end{tabular}

The table above is of special interest because the periods for which the data are avallable are comparable for the five different jears and represent that time of year (September) when the inflow and outflow are probably not materially affected by seasonal mun-off or excess irrigation water. The outflow from the valley during september can be assumed, with reasonable accuracy, to be all or nearly all ground-water mun-off. This was the actual condition during the measurements made in September 1934, for there was no contimuous flow through the channels of the streams in Ogden Valley, and irrigation water was so much in demand that none was being wasted.

The inflow into the valley during the years 1921, 1925, and 1934 includes the inflow both above and below the highest irrigated land. The inflow below the irrigated land consists mainly of return flow from ground waters, although a small amount of inflow may have been caused by direct irrigation run-off, particularly during the years 1921 and 1925. The inflow below the irrigated lands during August and September, 1921 and 1925, was comparable in amount and indicates no great difference in the ground-water level during those two years. The inflow below the irrigated land on September 15, 1934, was only 2 second-feet. The reduction of this inflow of 1934 below that of 1921 and 1925 was probably caused in the main by the excessive lowering of the ground-water level during 1934. However, a small amount of the decrease was probably due to the lack of imigation water and consequently less direct run-off or wastage of irrigation water. 
The inflow into the valley above the irrigated land was progressively less during september of the years 1894, 1921, 1925, 1928, and 1934--a. fact which would in itself indicate a similar decrease in the amount of outflow from the valley. However, the outflow from the valley decreased at a more rapid rate than the inflow above the irrigated 1 and. This was probably due both to more economy in the use of irrigation water, which decreased the direct inflow and seepage from irrigation water, and to a progressive decline in the level of the ground water.

A decline in ground-water levels is caused by a decrease in the amount of ground-water recharge or by increased withdrawals from the ground water. The precipitation between 1904 and 1930 was consistently above normal. A lowering of the ground-water levels between these dates would have been partly due to a decrease in the recharging of the ground water caused by more economy in the use of irrigation water. As a major part of the ground-water development in the valley was made about 1914, a part of the lowering of the ground-water levels between 1904 and 1930 would have been caused by these ground-water withdrawals.

Between 1921 and 1928 the rate at which the outflow decreased was greater than the rate at which the inflow above the irrigated land decreased. During the same period the precipitation was consistently above normal (see pl. 35), which indicates a more or less constant amount of recharge from precipitation. The development of ground water during that period was relatively small. Thus, the increase in the rate of decline of the outflow over the inflow to the valiey during this period was probably due to a more economical use of irrigation water, which decreased the recharge to the ground water and lowered the groundwater levels. The exceptional decrease in the stream flow in the valley during 1934 was, without question, due to a lack of precipitation, which resulted in lowered ground-water levels and reduced seepage from the ground-water body. The direct inflow of waste irrigation water was also reduced to practically zero during 1934. 
GROUND WATER

Occurrence

Ground water in Ogden Valley occurs in the pore spaces of the gravel, sand, and clay of the valley fill. Although clay may be as porous as sand and gravel, the pore spaces are so minute that little or no water will drain or can be recovered from saturated clay.

Two distinct types of conditions are encountered by wells in Ogden Valley. Wells that pass through the clay confining bed encounter water that is under artesian pressure, which in the lower parts of the valley (below an altitude of about 4,860 feet) is sufficient to produce flows at the surface. Drilled wells are used where artesian conditions will. be encountered. Wells that encounter water-table conditions in ogden Valley (ground water not confined under pressure) are usually dug. In the part of the valley that is underlain by the clay confining bed, dug wells penetrate only the surficial water-bearing material that lies above the clay bed. Water-table conditions are also encountered in the part of the valley Iying north, northeast, and east of the upper edge of the clay confining bed. (See pl. 36.) Most of the wells in this area are dug. Figure 21 shows the ground-water conditions in various parts

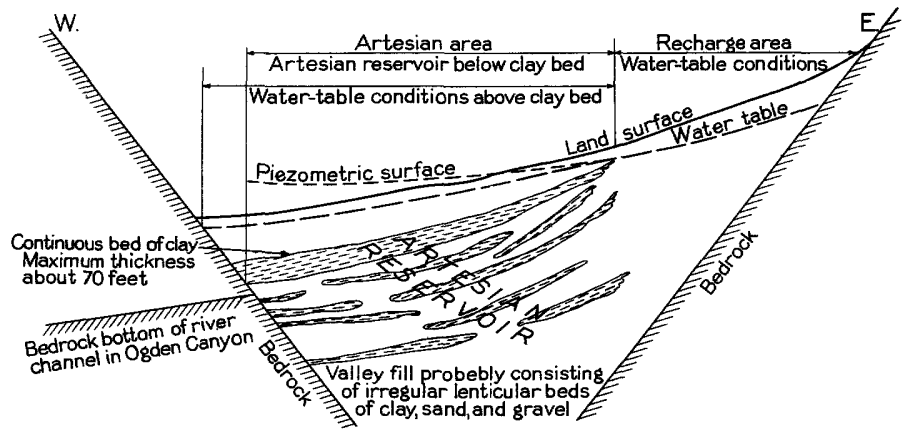

Figure 21.--Diagrammatic sketch of an ideal east-west section through Ogden Valley, Utah, showing ground-water conditions.

of the valley. The illustration is diagrammatic and is not drawn to scale. As indicated in the figure, the area underlain by the continuous clay bed is the artesian area. This is the area to the southwest of the dashed line in plate 36. The artesian reservoir is the ground-water 
reservoir that lies below the continuous clay confining bed. The area to the north, northeast, and east of the dashed line in plate 36 constitutes the recharge area of the artesian reservolr.

\section{Source}

The source of all or nearly all of the ground water in Ogden Valley is the rain and snow that fall upon the valley and upon the drainage areas of the streams entering the valley. A part of the precipitation that falls upon the land surface is carried off through stream channels, a part evaporates, and the remainder percolates directly into the ground. Some of the percolating water eventually reaches the groundwater body. Some of the stream water also percolates through the beds of the streams and eventually reaches the ground-water body. A part of the stream flow is diverted from the natural channels and is used for irrigation. Some of this diverted water reaches the ground-water body after seeping from irrigation canals, and some of it percolates downward after being applied to the land.

None of the water that falls on or is applied to lands in the artesian area--that is, the area underlain by the confining clay bed-reaches the artesian reservoir. Tests of permeability were made in the hydrologic laboratory of the United States Geological Survey on samples of both disturbed and undisturbed clay of the confining bed, and these tests all gave coefficients of permeability of less than 0.10 , showing that the clay is essentially impervious. (The coefficient of permeability of a material is the rate of flow, in gallons a day, through a square foot of its cross section, under a hydraulic gradient of 100 percent, at a temperature of $600 \mathrm{~F}$.$) There exists a considerable artesian$ pressure beneath the clay bed, which is greater than the pressure of the shallow water body above the clay bed, thus precluding any movement of water downward through the bed. Consequently, the water that penetrates to the water table in this area becomes a part of the shallow groundwater body that is separated from the artesian water by the confining clay bed, whereas the water that penetrates to the water table in the recharge area (see fig. 21) becomes a part of a ground-water body that is continuous with the artesian water and recharges the artesian reservolr.

There has been extensive faulting in the Ogden Valley region, and it is probable that some deep-seated water is contributed to the 
ground-water bodies in the valley through cracks and fissures in the bedrock. However, the quantity of such water is probably small.

\section{Movement}

The direction of movement of ground water in ogden Valley is approximately parallel to the general slope of the land surface in the valley, which is from the north, northeast, east, and southeast toward the head of ogden Canyon. The ground water in the recharge area moves down gradient toward the upper edge of the clay confining bed. If the artesian reservoir has been partly depleted, some or all of the water moving from the recharge area will enter the artesian reservoir, thus becoming artesian water. If the artesian reservoir is full and incapable of receiving more water, water from the recharge area will pass over the upper edge of the clay confining bed and become a part of the shallow ground-water body above the artesian reservoir.

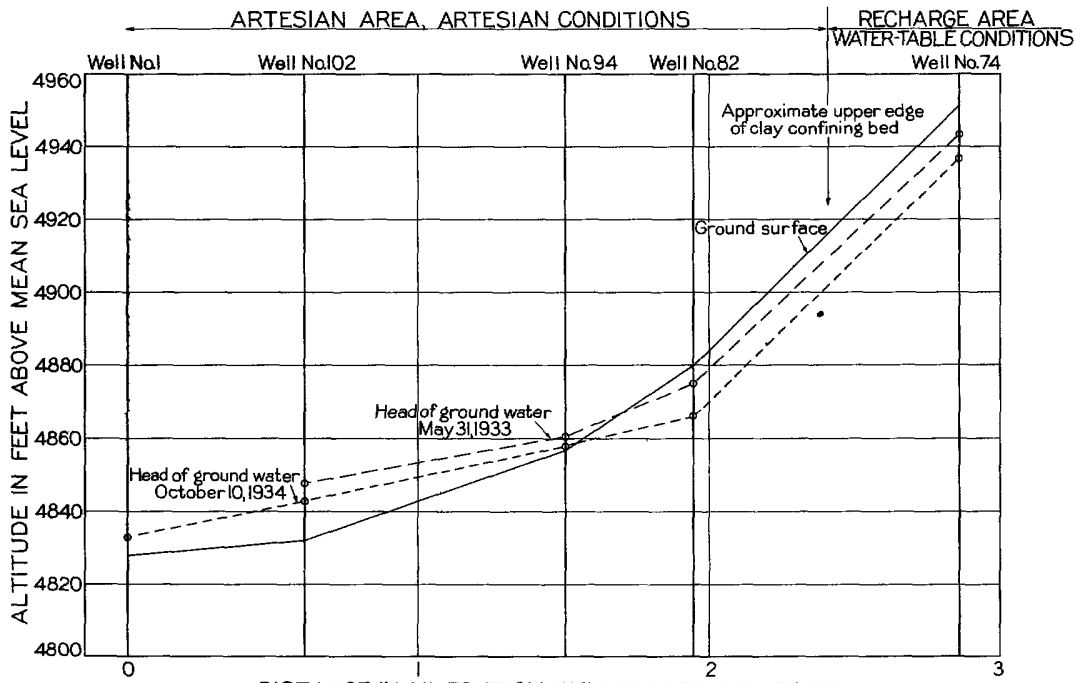
Figure 22,--Profiles between Artesian Park and well 74, Ogden
Valley, Utah, showing land surface and levels at which water
stood in welis on Iay 31,1933 , and 0ctober 10, 1934.

The available information was not sufficient to construct a map of the plezometric surface (pressure-indicating surface) In the artesian area, but figure 22 shows profiles of the piezometric surface, water table, and land surface between Artesian Park, and well 74 on Hay 31, 1933, 
and October 10, 1934. The profile on May 31, 1933, shows the conditions when ground-water levels were at about their highest stage during the investigation. This was before the city of Ogden artesian wells were pumped with air during the summer of 1933. The profile on October 10 , 1934, shows the conditions when ground-water levels were at about their lowest stage during the investigation. This was shortly after the heavy summer withdrawals at Artesian Park. Figure 22 shows that the gradient of the water table in the recharge area, about 84 feet to the mile, was steeper than the gradient of the plezometric surface in the artesian area, which was about 17 feet to the mile.

\section{Fuctuations of water level}

Ground-water levels and artesian pressures are in an almost constant state of fluctuation. These fluctuations are produced by different causes. Of great significance are the declining water levels or pressures that indicate discharge from the ground-water body and, conversely, rising water levels or pressures that indicate recharge of the ground-water body. Periodic or continuous records of water levels or pressures, if rightly interpreted, indicate whether the ground-water body is being built up or depleted, whether it stands at a higher or lower level than previously, whether a larger or smaller amount of water can safely be withdraw, and whether existing developments of ground water are being damaged by overdraft. For these and other reasons it is desirable to obtain more or less continuous records of the ground-water levels in an area, so that the ground-vater problems and conditions can be more clearly understood. Much can be learned from records covering a period of 1 or 2 years, but it is more desirable to obtain unintermupted records over long periods.

Test welis and continuous records.-- At the beginning of this investigation it was found that no wells existed in which the necessary records of fluctuations of water level could be obtained. For this reason, and to obtain accurate records of the nature of the valley fill, six test wells were drilled in the valley during August and September 1932, at the locations shown in plate 36. At two of these well sites an additional well was dug to a depth of about 4 feet. Two we1ls, 68 and 90 feet deep (wells 101 and 102, respectively), were arilled in adaition to the dug well at the first site, the three spaced about 50 feet apart in the form of an equilateral triangle. At the second site, two 
weIls, 40 and 108 feet deep (wells 81 and 82 , respectively), were drilled in addition to the dug well, the drilled wells spaced about 50 feet apart and the dug well about 75 feet from the two drilled wells. At the third site two wells (73 and 74) were drilled 14 and 100 feet deep and about 50 feet apart. The logs of the six drilied wells are shown in plate 40. All eight wells were equipped with float-type automatic water-level recorders that gave continuous records of the fluctuations of the water levels. The casings of the flowing artesian weils 101 and IO2 were extended above the surface until the wells ceased to flow, and the water-ievel recorders were installed so as to record the fluctuations of water level representing the piezometric surface. Recorders were operated on the two dug wells for 16 months and on the 14-foot well at the upper site for 19 months. The records from weils $74,82,101$, and 102 cover a continuous period of about 33 months previous to July I, 1935. The fluctuations of the water level in wells 101 and 102 were generally very similar, differing only in magnitude and in time of occurrence. This was also true of wells 81 and 82 and of weIls 73 and 74. The hydrograph of only the deepest well at each site is therefore reproduced in plate 37. These hydrographs are based on the water level at noon each day, as taken from the continuous instrument record. In addition to the continuous records obtained from the test wells, a recording pressure gage was operated on well 50 and a waterlevel recorder on well I for different periods. The hydrographs obtained from these two wells are also shown in plate 37 . In conjunction with the hydrographs of the wells, plate 37 also shows withdrawal of water at Artesian Park, the precipitation at Ogden, the surface-water Inflow to the valley through the South Fork of the Ogden River, and the times of major changes in the operation of the wells at Artesian Park. Periodic measurements.--In addition to the wells on which automatic recording devices were used, hand measurements of water level were also made at approximately weekly intervals in 21 other weils distributed throughout the valiey. The hydrographs derived from these measurements are shown in plate 38 , in which the flow into the valley of the South Fork of the Ogden River is also shown for comparison. Several other miscellaneous measurements were made on other wells, and these are given in the table at the end of the report.

Annual cycles.--The magnitude of the annual cycle depends upon the amount of recharge and discharge of ground water. Annual cycles of the 
fluctuations of the water table are shown by the hydrograph of well 74 (plate 37) and by some of the hydrographs in plate 38. Similar cycles of the fluctuations of pressure in artesian wells are shown in plate 37. During the period of observation the water level in well 74 had an annual cycle of 8 to 9 feet. The records of other water-table wells showed cycles of about 2 to 30 feet or more. The annual high point of the water table and artesian pressure occurs during April, Hay, or June, depending upon the lateness of the spring thaw and run-off. The hydrograph of well 74 (pl. 37) shows two peaks during the spring of 1933. Comparison of this hydrograph with that of the South Fork of the Ogden River for the same period shows a marked similarity. The first peak in the hydrograph of well 74 was caused by the early spring thaw in ogden Valley and in areas of slightly higher altitude adjacent to the valley. The local run-off resulting from this thaw replenished the ground water in the recharge area. The second peak was due to the general spring thaw that occurred later at higher altitudes. As the surface mun-off resulting from this thaw passed over the recharge area the ground water was replenished. The high peak in the hydrograph of well 74 during April 1934 was apparently due only to the spring thaw in the valley, because the hydrograph of the South Fork of the Ogden River shows very little spring run-off as a result of the spring thaw at higher altitudes.

A large amount of water is diverted for irrigation during the perlod of the spring run-off, and the application of this water to lands In the recharge area is in part the cause of the rise of the water table in the spring. The effect of fall imigation and fall rains on the ground-water levels is show by peaks in the hydrograph of well 74 during September 1933 and October 1934. (See p1. 37.)

The hydrograph of well 82 appears to have two peaks each year. The first occurs in April, May, or Jume and the second in November or December. The causes of the second peak are both artificial and natural. As shown in figure 23, the withdrawals at Artesian Park noticeably affect the water level in well 82 . When the rate of withdrawal at Artesian Park is increased, the water level in well 82 declines. Converse1y, a decrease in rate of withdrawals at Artesian Park produces a rise in water level in well 82. Heavy withdrawals at Artesian Park cease at about the same time each year that recharge due to fall irrigation and fall rains occurs, and the individual effects of the two factors on the ground-water levels cannot therefore be separated. From a comparison of 
the dischargg at Artesian Park and the hydrograph of well 74 (p1. 37) it is not apparert whether the withdrawals at Artesian Park affect the water table in the recharge area. However, prolonged periods of heavy draft at Artesia. Park would tend to lower that water table.

1933
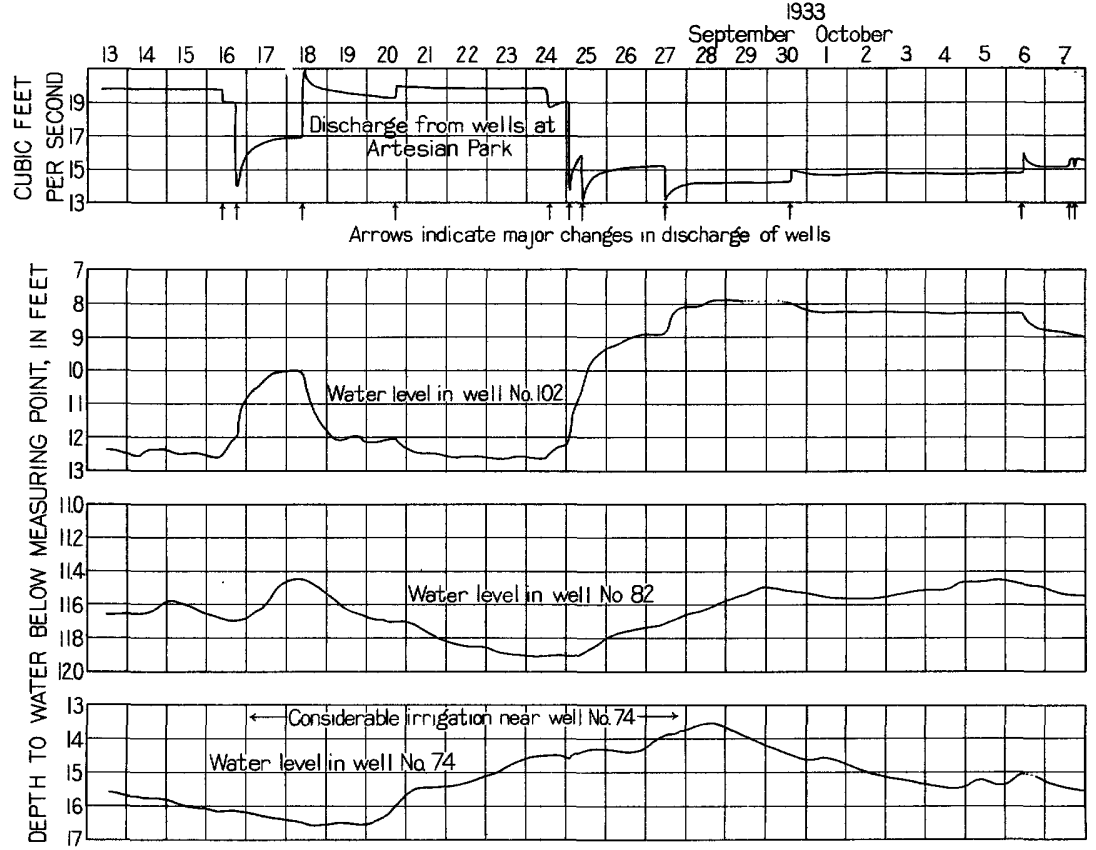

Figure 23.--Discharge from wells at Artesian Park and water levels in three wells in Ogden Valley.

The hydrograph of well 102 (pl. 37) shows the annual cycle broken by the withdrawal at Artesian Park. It is apparent from the hydrograph that during the period of record the water level in well 102 never reached its highest possible point in the spring, because increased summer withdrawals at Artesian Park began while the water level was still rising. The artesian pressure in well 102 responds very rapidly and very markedly to any change in rate of withdrawal at Artesian Park. This is clearly shown in plate 37 and figure 23. The yield of a flowing well is dependent in part on the artesian pressure in the well, and if this is reduced as a result of other withdrawals in the vicinity, the jield of the well will diminish. The hydrographs of wells 1 and 50 (pl. 37) show the pressure on the artesian reservoir at Artesian Park, the general pressure head under which the withdrawals from nearby wells 
were being made, and the rapld changes in pressure due to changes in rate of withdrawal.

Water levels during 1925, 1926, and 1928.--A few measurements of the water levels in the wells at Artesian Park were made in 1925, 1926, and 1928 under the direction of the State engineer. These are shown in the table of well measurements. The avallable data concerning the conditions governing the withdrawals at Artesian Park at the time of these measurements are insufficient to allow an accurate comparison with the measurements made during the present investigation. However, the best interpretation of the data indicates that the artesian pressures in 1933 may have been slightly greater than those in 1925, 1926, or 1928 but that the difference was probably not large. It is apparent from the table of well measurements that the pressure in a well at Artesian Park is considerably changed when other wells in the field are opened or closed, or when the air compressors are operated or shut down. This change is also shown by the hydrographs of wells 1 and 50 in plate 37.

Changes in atmospheric pressure, transpiration by plants, and evaporation.--Daily fluctuations of water level in wells occur in most localities. During the growing season in Ogden Valley the water level In shallow wells and the stage of streams fluctuate daily owing to transpiration by plants and to evaporation. Figure 24 shows fluctuations of this type. The water level in well 80 , as shown by the hydrograph in figure 24, begins to decline in the morning, when the sedges growing around the well begin drawing on the ground water. This decline continues until late afternoon, when plant growth essentially ceases. The water level then rises until the following morning, when the fall is again repeated. The hydrographs of the streams given in figure 24 show similar fluctuations except that there is a lag in time of occurrence. This lag is presumably a function of the distance of the gaging stations below the area of transpiration and evaporation.

The water levels and pressures in artesian wells commonly fluctuate with changes of atmospheric pressure. In some wells such fluctuations are small, but in others the wells function as perfect water barometers. Figure 25 shows fluctuations of this type together with the record of atmospheric pressure at Artesian Park, where a recording barometer was maintained. The curve showing atmospheric pressure has been inverted to make the comparison more clear. 

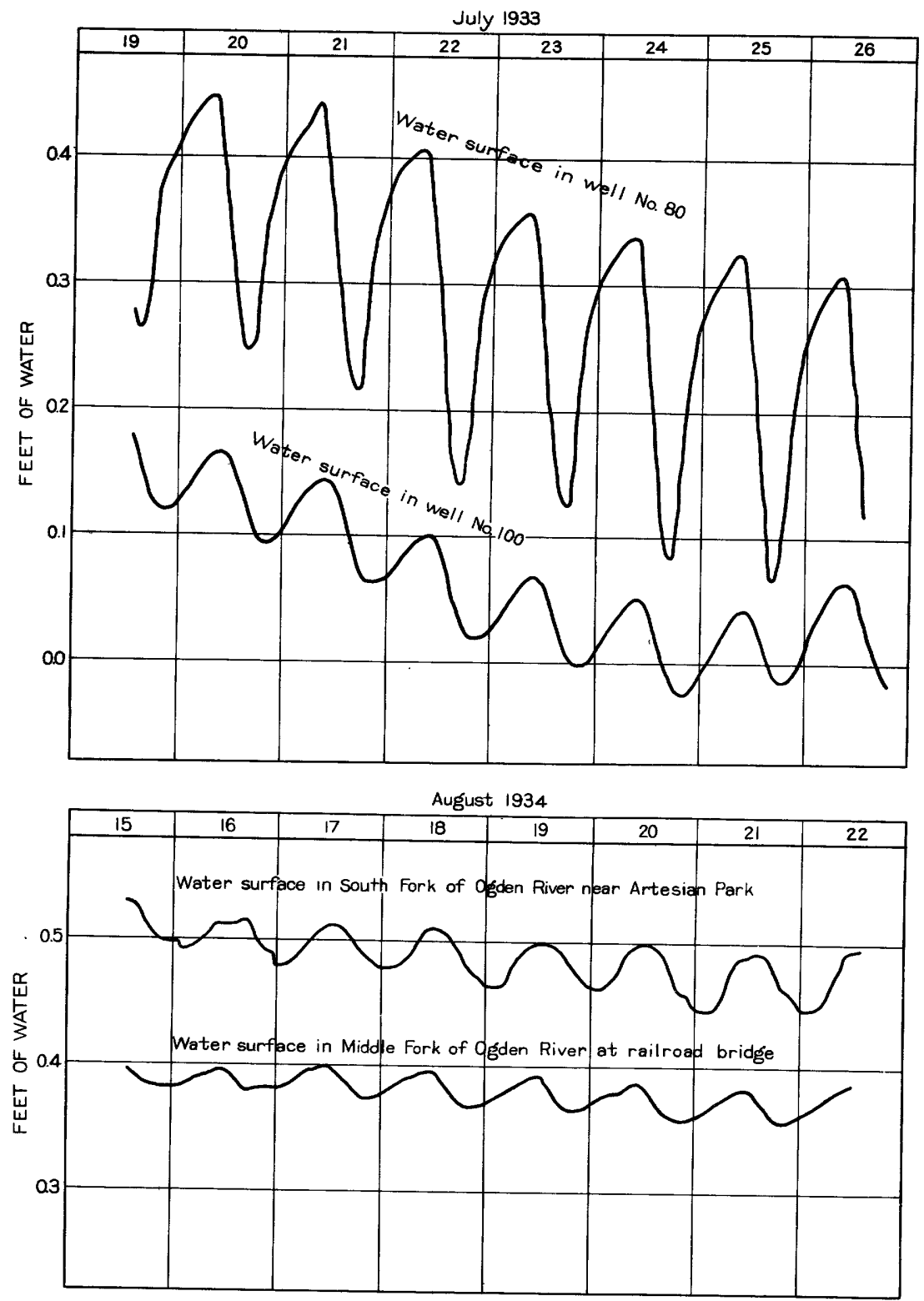

Figure 24.--Hydrographs of streams and wells in Ogden Valley, Utah, showing effects of plant transpiration on water levels. $1468240-37-5$ 
Water-level fluctuations due to transpiration and to changes in barometric pressure are distinctly different with respect to time of occurrence. During the midday period the trend is downard on the transpiration curve, whereas it is generally upward on the barometric curve.

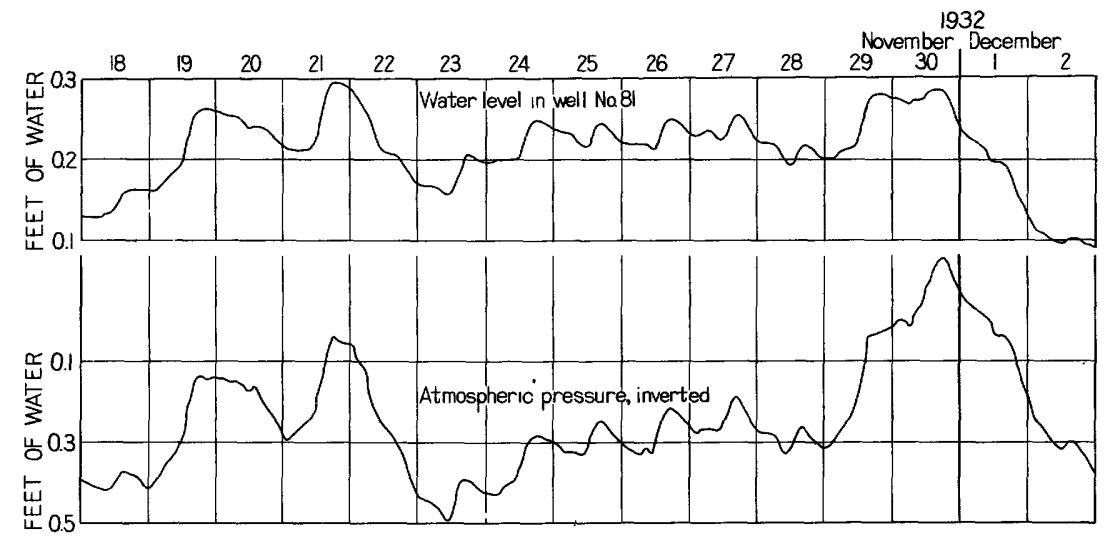

Figure 25.--Hydrograph of well 81 and graph of fluctuation of atmospheric pressure in Ogden Valley, Utah, showing barometric type of water-level fluctuation.

Fluctuations caused by earthquakes.-Another type of fluctuation of ground-water level that is not frequently observed is that due to earthquakes. Instrumental records of earthquakes in Utah were first obtained in observation wells during this investigation and a similar investigation by the United States Geological Survey near Salt Lake City. Automatic water-level recorders in several wells in Ogden and Salt Lake Valleys registered water-level fluctuations produced by the earthquake of December 30, 1932, which centered in western Nevada. On March 12 , 1934, an earthquake occurred in Utah with 1ts epicenter about 65 miles northwest of Ogden Valley, near the north end of Great Salt Lake. This earthquake consisted of several shocks, and it disturbed ground-water levels to a considerable extent, although no appreciable permanent change in the ground-water levels of wells in Ogden Valley was detected except that in well 74, which was raised and remained about 0.75 foot higher than before the shocks. Figures 26 and 27 are exarples of fluctuations of water level produced by earthquakes. This subject is discussed in more detail in another paper.

$10 /$ Leggette, R. M., and Taylor, G. H., Earthquakes instrumentally recorded in artesian welis: Selsmol. Soc. America Bull., vol. 25, pp. 169-175, 1935. 
Comparisons of ground-water levels during 1933, 1934, and 1935.-The effects of the drought of 1933-34 are shown in the hydrographs of all wells that were measured. The lowest water levels during the period of investigation occurred in September or october, 1934. The quantity of water available for ground-water recharge in the spring was very small;

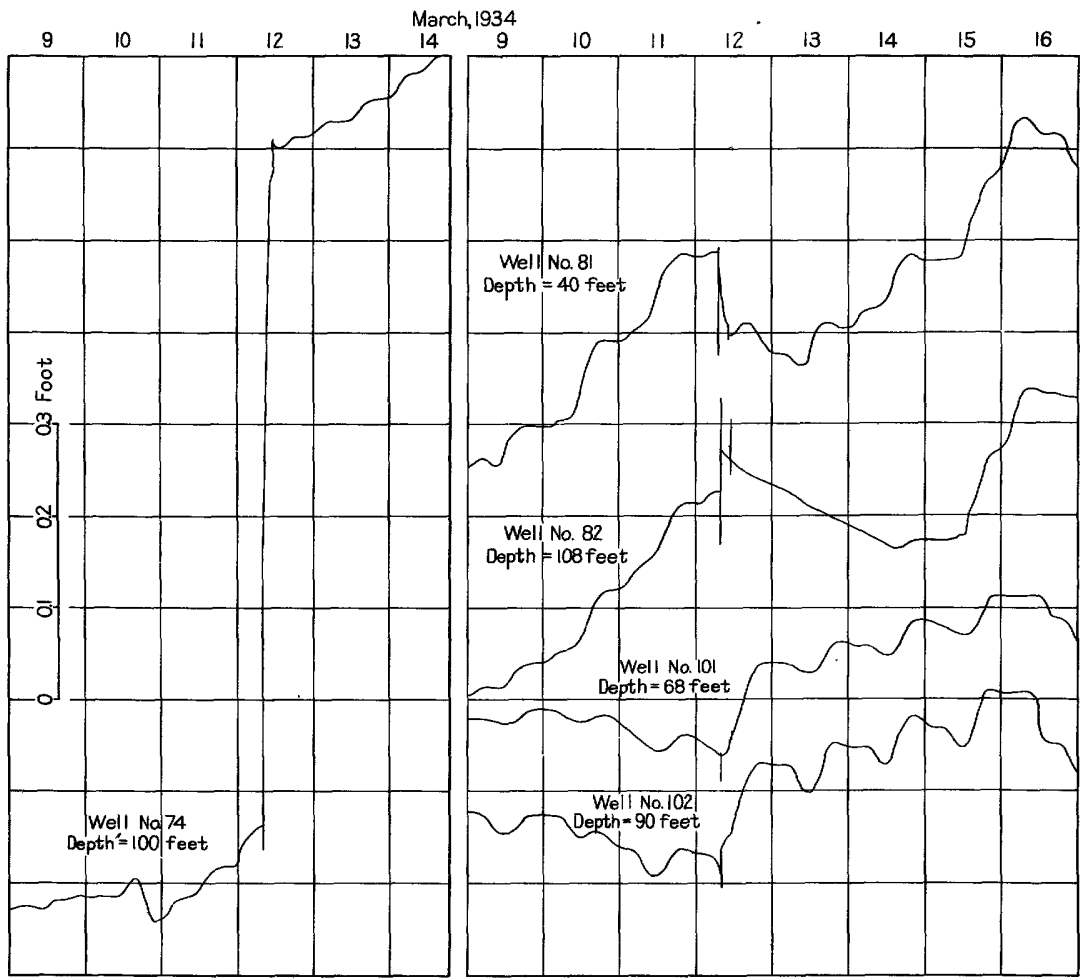

Figure 26.--Hydrographs of five wells in Ogden Valley, Utah, showing fluctuations of water levels in wells caused by earthquakes on March 12, 1934.

consequently there was but little recharge, and the period during which it occurred was short. This, together with heavier withdrawals, produced a greater and more rapid decline of ground-water level than usual during the sumer of 1934. However, a comparison of the water levels during February or Narch (the period just before recharge occurs in the spring) of 1933, 1934, and 1935 shows that the ground-water levels were about the same each year or slightly higher in 1935. The water level in well 74, in the recharge area, in February 1935 was about 2.25 feet higher than in February 1934 and about 3 feet higher than in 
Febmuary 1933. In Febmary 1935 the water level in well 82, near the upper edge of the artesian area, was about the same as in February 1934 and about 1.5 feet higher than in February 1933. The water level in well 102, near Artesian Park, in February 1935 was about 2 feet lawer

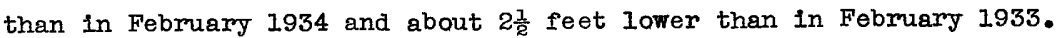

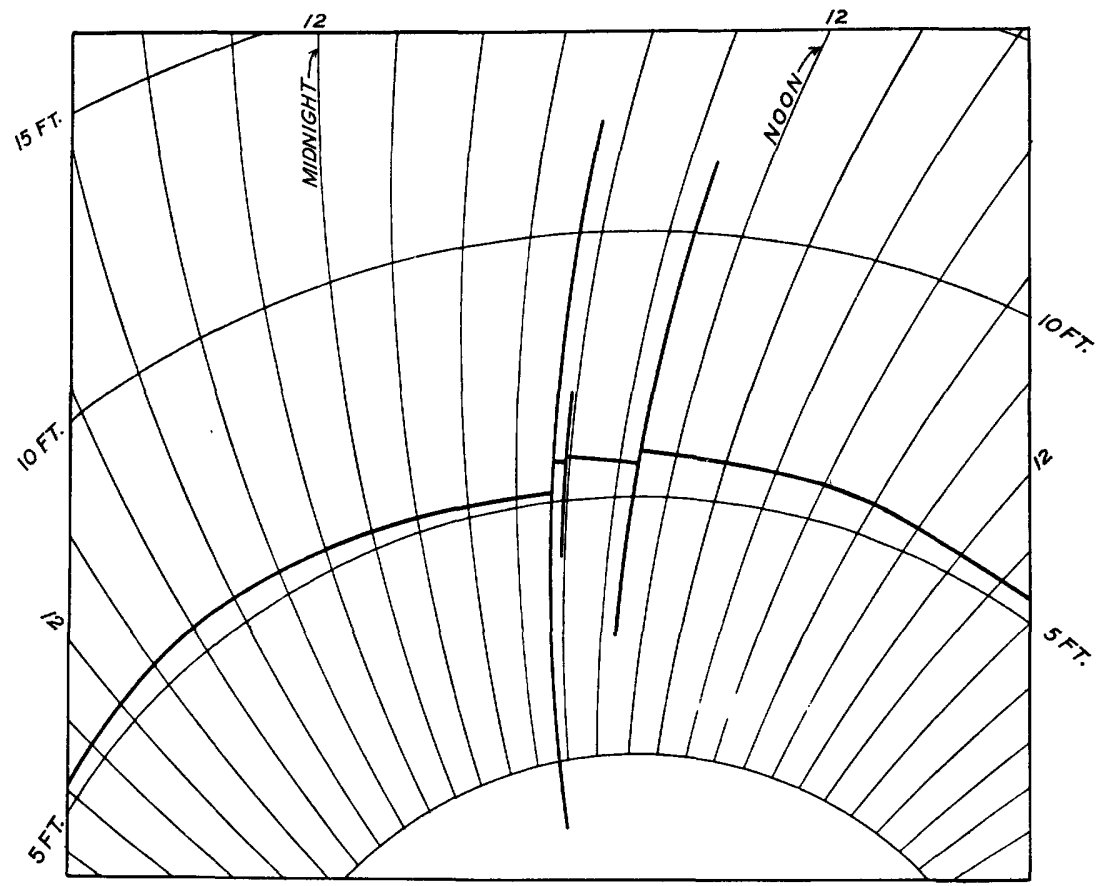

Figure 27.--Graph from recording pressure gage operating on a 133-foot artesian well in Ogden Valley, Utah, showing effect of earthquake of March 12, 1934.

The water level in this well is directly affected by the withdrawals at Artesian Park, and, as these withdrawals were greater in 1933 than in 1932 and still greater in 1934, it was to be expected that the water levels in wells near the park would reflect the amount of withdrawal in the preceding period. Thus, notwithstanding the drought and heavier withdrawals during 1934, the ground-water levels before the 1935 spring recharge stood at about the same level as during the same periods in 1934 and 1933, except in the vicinity of the heavy withdrawals. Moreover, the water table in the recharge area stood higher in February of 
each succeeding year from 1933 to 1935. These records are indicative of the reliability of the ground-water supplies in general and show that the ground water in Ogden Valley was not exceptionally depleted nor dangerously lowered during 1934. With normal recharge during the spring of 1935, the ground-water supply in Ogden Valley should have been as plentiful or more plentiful than at any time during the period of this investigation.

Summary.--The following conclusions have been reached from a study of the available hydrographs showing the fluctuations of water level in wells in Ogden Valley: (1) The annual fluctuations range from a few feet to more than 30 feet, according to location, recharge, and discharge. (2) The period of high ground-rater levels occurs during April, May, or June of each year, the time of the highest levels varying somewhat from year to year with the time of spring recharge. (3) The annual period of low ground-water levels occurs in the later part of the winter unless unusual conditions prevail. (4) Ground-water levels rise as a result of recharge from irrigation as well as from precipitation and seepage from streams. (5) The withdrawals at Artesian Park probably affect artesian pressures in the entire artesian reservoir and also to some extent the level of the water table. (6) Because of the heavy summer withdrawals at Artesian Park, the maximum artesian pressures that would naturally. result from spring recharge are never attained in the vicinity of the park. (7) The ground-water levels before the spring recharge were about the same in 1935 as in 1934 and 1933, notwithstanding the drought and the heavier withdrawals in 1934. The water table in the recharge area was higher in February 1935 than in February of either 1933 or 1934.

\section{Recharge}

The ground-water reservolrs of ogden Valley are recharged in part by water that falls as rain or snow on the valley and excess irrigation water and in part by water that seeps from the channels of surface streams and irrigation canals. The water that sinks to the water table above the impervious clay bed that covers the artesian reservoir becomes a part of the shallow ground-water body but does not reach the artesian reservolr. The water that sinks to the water table in the recharge area becomes a part of the ground-water body in this area with water-table conditions. This body of water is continuous in its upper part with the 
shallow water body lying above the confining bed and in its lower part with the artesian reservoir. (See fig. 2l.) This water is in part discharged by evaporation and transpiration, in part by seepage into the streams, and in part by percolation into the artesian reservoir or into the shallow water body above the confining bed.

Seepage from streams.--Seepage from streams is probably the chief source of ground-water recharge. This type of recharge was well shown by a test made on the South Fork of the Ogden River during the summer of 1925 by H. W. Browning, of the office of the State engineer. On July 20, all the water in the South Fork was being diverted at the mouth of South Fork Canyon for irrigation, and the channel of the stream was dry for a distance of more than 2 miles below the diversion. Water began to flow in the channel again at a point about half a mile southeast of Huntsville. On that day about 34 second-feet of the flow at the mouth of the canyon was turned back into the dry creek channel. Two days later the water had reached a point only about a mile below the place of diversion, and more than a mile of the channel still remained dry. On July 23, 1925, 43 second-feet was flowing in the stream channel just below the point of diversion at the mouth of the canyon, but the flow at a point approximately 1 mile farther down the channel was only about 25 second-feet, showing a loss of about 18 second-feet in 1 mile of channel. The water in the stream also still lacked about 3,000 feet of reaching the point of return flow in the channel. On July 31, when the conditions of flow and seepage were still about the same as on July 23, the entire flow of the South Fork, about 49 second-feet, was turned into Its channel, all diversions being stopped. On August 1 it was found that only 10 second-feet finally reached the point of return flow. Thus there was a loss of about 39 second-feet through the 2-mile section of channel. This loss was a contribution to the water table in the recharge area.

At no time during the winter of 1933-34 was the flow continuous in the channel of the South Fork in Ogden Valley--that is, there were dry stretches of stream channel. The diversions during the winter were not measured but did not generaliy exceed 8 second-feet and during some parts of the season were less than 5 second-feet. During November and December, 1933, and January, February, and a part of March, 1934, the flow of the South Fork at the United States Geological Survey gaging station fust above the mouth of the canyon ranged from about 35 to 45 
second-feet. (See plates 37 and 38, in pocket.) The recharge to the ground-water body from the channel seepage of the South Fork was therefore about 30 to 35 second-feet during the winter of 1933-34. When the entire flow of the South Fork at the mouth of Its canyon is not diverted for irrigation there is ground-water recharge from channel seepage probably amounting to a maximum of about 40 second-feet.

Similar conditions exist in the channels of the Middle and North Forks of the Ogden River, although the amount of ground-water recharge from each of these streams is probably less than that from the south Fork. Several smaller streams that flow into Ogden Valley contribute smaller amounts of ground-water recharge in a like manner, especially during the spring run-off.

Penetration of precipitation and irrigation water.--The surface materials in Ogden Valley, especially those in the recharge area, are sandy and permeable in most places. Thus the conditions are very favorable for the rapid penetration of rain or melting snow. Some of the slopes of the mountains that surround the valley drain directly onto the valley floor and not into the adjoining streams. The rain falling on these slopes and the water from melting snow on them produce many small streams for short per1ods, and these streams rapidiy flow onto the ralley fill, into which the water sinks. A major part of this water becomes ground water. The permeable surface material also perm mits the rapid penetration of excess irrigation water as well as seepage from the irrigation ditches and canals. When the irrigation water is sparingly applied the ground-water recharge from this source is small. However, during the early part of most irrigation seasons there is a coplous supply of water, and most irrigators therefore overirrigate rather than underirrigate, with the consequent penetration of relatively large quantities of water beyond the reach of evaporation and transpiration. The water thus lost from overirrigation becomes a part of the ground-water body. It is well known by the farmers in the valley that the discharge of low-lying springs increases soon after the lands above the springs have been heavily irrigated and that the water levels in wells rise rapidiy soon after the lands in the vicinity have been irrigated. This rise of ground-water level is evident from the hydrographs of the observation wells show in plate 38 and the hydrograph of well 74 shown in plate 37. A more detailed example of ground-water recharge from Irrigation is show by the hydrograph of well 74 in figure 23. 
Quantitative estimate.--The water levels in several wells in the valley were measured at weekly intervals for a period of about a year, beginning in october 1932. Eight of these wells are in the recharge area--that is, in the area which is not underlain by the confining bed. The recharge period of the year ending September 30, 1933, may be regarded as extending from November 1932 to June 1933, but the principal rise in the water levels occurred in the spring, as is show in plate 38. The following table gives the pertinent data relating to the rise of water levels.

Rise of water levels in observation wells in the recharge area of Ogden Valley during the recharge perlod from November 1932 to June 1933.

\begin{tabular}{cccc}
\hline $\begin{array}{c}\text { Drainage area } \\
\text { and well }\end{array}$ & $\begin{array}{c}\text { Rise of } \\
\text { water level } \\
\text { (feet) }\end{array}$ & $\begin{array}{c}\text { Average rise } \\
\text { water level } \\
\text { (feet) }\end{array}$ & $\begin{array}{c}\text { Approximate } \\
\text { area } \\
\text { (acres) }\end{array}$ \\
\hline
\end{tabular}

South Fork:

$\begin{array}{lllll}136 & 10 & & & \\ 139 & 21 & . & 14 & 3,500 \\ 146 & 12 & & \end{array}$

Middle Fork:

$\begin{array}{llll}65 & 3 & & \\ 71 & 4 & 5 & 1,800 \\ 75 & 8 & & \end{array}$

Lower North Fork:

59

Jpper North Fork:

56

Weighted average

Total.
6

30

13.5
$30 \quad 1,600$

$6 \quad 1,700$
Total

A study of the well records and other data led to the conclusion that the average specific yield of the valley fill in the byelt of watertable fluctuation in the recharge area is probably about 20 percent, or, more specificaliy, that a rise in the water table of 5 feet represents a storage of about 1 foot of water. On this basis the weighted average rise of 13.5 feet represents an increase in storage equal to a layer of water 2.7 feet thick covering the entire recharge area of about 8,600 acres, or about 23,000 acre-feet. The total recharge in the valley during the year included not only this increase in storage but also the discharge during the period of rise, the recharge during the period of declining water table, and the recharge of the shallow valley fill 
overlying the confining bed by precipitation and irrigation on that fill. This method appears to give a larger ground-water supply than the discharge method described later in this report, suggesting that the estimate of specific yield may be somewhat too high. It is, however, of great value in giving independent evidence of large annual recharge and a large perennial supply of ground water.

Water spreading.--The fact that water applied to the surface of the land in the recharge area penetrates the soil so readily that groundwater recharge takes places suggests a practical method of artificially recharging the artesian reservoir. Successful recharging of the ground waters of southerm California has been accomplished in recent years by a method termed "water spreading". $11 /$ This method consists of diverting the water from streams during flood stages, or at other times when the water is not being used, and applying it to the surface of the land in the recharge areas of the ground-water bodies. Several variations in the details of the application of the water have been used, some more successful than others. It is probable that the water-spreading method could be used to good advantage in Ogden Valley.

In addition to the benefits derived from naturaliy or artifieially recharging a depleted ground-water reservolr, surplus water is placed in ground storage, and this results in a greater stream flow later in the season when water is most needed. Fortier called attention to the fact that the surface outflow from Ogden Valley was greater than the inflow (the difference increased during the summer of 1894) and that this was no doubt the result of the diversion and penetration of large quantities of water in the early part of the season, when water was abundant. Large amounts of water were used for irrigation on the higher lands in the early part of the season, and this excessive irrigation resulted in the storage of large amounts of water in the ground, which later seeped out and returned to the stream channels.

Surplus water in the spring can still be placed in ground storage by heavy early irrigation or by the more modern methods of water spreading. The benefits to be derived from water spreading in ogden Valley are as follows: Spring flood water that otherwise may be wasted will be

11/ Lane, D. A., Increasing storage by water spreading: Am. Water Works Assoc. Jour. vol. 26, no. 4, pp. 421-429, 1934; Surface spreading operations by the basin-method and tests on underground spreading by means of wells: Am. Geophys. Union Trans., 15th Ann. Meeting, pt. 2, pp. 523-527, 1934 .

12 Fortier, Samuel, Preliminary report on seepage water and the underflow of rivers: Utah Agr. Coll. Exper. Sta. Bull. 38, p. 21, February 1895. 
conserved; the water table in the recharge area of the artesian reservoir will be maintained at a higher level, and pressures in the artesian reservoir will therefore be greater; and the stream flow from the valley will be increased during the sumer, when the water is most needed for irrigation, because excess water will have been put into ground storage.

\section{Discharge}

Both natural and artificial discharge of ground water take place in Ogden Valley. Natural discharge occurs as flow from springs, return flow to streams, evaporation from soll, and transpiration by plants. Artificial discharge occurs by the withdrawal of water from flowing and nonflowing wells.

Shallow water body above artesian confining bed.--In the lower parts of Ogden Valley the stream channels lie about 80 feet below the 4,900-foot bench. The stream valleys have been cut into about the top 25 feet of the clay confining bed. Along the sides of the stream valleys spring seepage occurs at many places at the contact of the clay bed and the overlying sand and gravel. This seepage is discharge from the shallow ground-water body above the artesian confining bed. In the lower areas the ground water lies at relatively shallow depths, and a large amount of water is dissipated by plant transpiration. This is very noticeable at many places along the contact of the clay bed and the overlying sand and gravel, where vigorous growths of cattails and assoclated plants occur, even on the steep slopes flanking the stream valleys. In the lowest areas of the stream valleys the shallow groundwater body lies very close to the surface, and the water table probably fluctuates with the level of the water in the streams. In these areas there is a large discharge of ground water by transpiration, the areas supporting many willows, cattalls, and assoclated plants, and considerable ground water is also lost by evaporation from the soll.

On the 4,900-foot bench, between the stream valleys, in the area underlain by the artesian confining bed, ground water occurs at relatively shallow depths and supplies the seepage that takes place along the contact of the clay bed and the overlying sand and gravel along the flanks of the stream valleys. Only small amounts of water are evaporated directly from the soll in this area, but somewhat larger amounts are transpired by trees and by other deep-rooted plants. Water for domestic supplies is withdrawn from several shallow dug wells in this 
area, but the total withdrawal is small. Much of the increase in flow of the streams in the area underlain by the clay confining bed is derived from the shallow ground water above the confining bed.

Recharge area.- The water table in the recharge area lies at varyIng depths below the ground surface, the depths increasing toward the foot of the mountains. In some parts of this area transpiration by trees and other plants occurs, but in general the losses by transpiration and evaporation are relatively small. Most of the ground-water discharge occurs by percolation into the artesian reservoir, percolation into the shallow ground-water body above the artesian confining bed, and seepage into the streams. The springs at the head of Huntsville Spring Creek are regarded as discharge from this water body.

The amount of artificial discharge from the recharge area is very small, because only a few shallow dug wells are used for domestic supplies. During the summer of 1934 five large pits were dug in the recharge area by power shovel to provide irrigation water for the relief of drought conditions, but although water was obtained at relatively shallow depths, the total amount of water pumped from the pits was rather small. The Wangsgard sump, in the NWt sec. 21, T. 6 N., R. 2 E., had been dug and used in previous years, but it was enlarged in 1934. The water level in this sump stood about 20.5 feet below the surface on September 10, 1934. The water level in a second sump, dug in the NW $\frac{1}{4}$ SW $\frac{1}{4}$ sec. 21, T. 6 N., R. 2 E., stood about 10.5 feet below the surface on September 15, 1934. According to reports, about 1.25 secondfeet was pumped from this sump during a period of about 3 weeks in late June and early July, 1934. The water level in a third sump, dug in the SE $\frac{1}{4} S E \frac{1}{4}$ sec. 31, T. 7 N., R. 2 E., stood about 12.5 feet below the surface on September 15, 1934. A fourth sump, in the SW $\frac{1}{4} N E \frac{3}{4}$ sec. 14, T. 6 N., R. 2 E., was about 20 feet deep, but it was dry on September $13,1934$.

Artesian reservoir.--The amount of water lost from the artesian reservoir by upward movement through the clay confining bed is small. Laboratory determinations of the permeability of the clay bed showed that its coefficlent of permeability was less than 0.10, and the bed is considered to be essentially impervious.

Some water may percolate from the artesian reservoir into the head of Ogden Canyon. The altitude of the bottom of the clay confining bed in wells 101 and 102 is about 4,777 feet above sea level. The altitude of the bedrock at its lowest point at the Pine View dam site, about a mile downstream from the head of Ogden Canyon, is about 4,680 feet above 
confining bed lies at least 50 feet above the bedrock channel at the head of the canyon. This condition apparently allows the escape of some water from the artesian reservoir through a relatively narrow section at the head of the canyon, over the bedrock and under the clay confining bed. It could not be determined whether the Pioneer Dam has a cut-off wall that extends to bedrock. If such is the çase, there would be no underflow beneath the dam. That such underflow, if any exists, is small is indicated by a series of stream-flow measurements made on the Ogden River through Ogden Canyon on September 20, 1934. (See pp. 114-116.) The entire flow of the Ogden River at the mouth of its canyon, amounting to 14.3 second-feet, was return flow below the Pioneer Dam, which is just below the Pine View dam site. Of this flow, only about 3.8 secondfeet was return flow within about 1 mile below the Pioneer Dam. The remaining 4 miles of channel showed a more or less consistent gain through its entire length. The gain in flow of the Ogden River as it passes through the canyon is chlefly the result of ground-water seepage from the bedrock canyon walls, or perhaps in part from pipe-line leakage. A certain amount of variation in rate of gain is to be expected, because the canyon walls consist of different kinds of rock.

It is not definitely known whether the clay confining bed at the west and south margins of the artesian reservoir is in close contact with the bedrock of the adjacent mountains. However, near the head of the canyon there are exposures of the clay only a short distance from the bedrock of the mountains, and therefore the escape of water from the artesian reservoir along this contact is probably not large.

If there is little underflow beneath the Pioneer Dam, water that is discharged from the artesian reservoir in the narrow section beneath the bottom of the clay bed and in the bedrock channel at the head of the canyon must nearly all come to the surface in the lower parts of the valley or the upper part of the canyon above the Ploneer Dam. This is also true of the water that is discharged along the contact of the clay bed and the bedrock of the mountrins at the west and south margins of the artesian reservoir. This discherge from the artesian reservoir becomes a part of the shallow ground-water body in the lower part of the valley and eventually seeps into streams, evaporates, or is transpired by plants.

As shown by the hydrographs in plate 39 (in pocket), the total stream flow from the valley was greater during the period August to 
November, 1933, than the sum of the flow of the North, Middle, and South Forks and Huntsville Spring Creek above Artesian Park for the same period. However, during the period June to September, 1934, the reverse was tmue. At times the transpiration and evaporation losses in the lower part of the valley are large, and this might account for the total surface-water outflow from the valley being less than the combined flow of the tributary streams as measured above Artesian Park. However, there is considerable return flow to streams in the lower part of the valley, and at such times it is to be expected that the surface-water outflow from the valley would be greater than the combined flow of the tributary streams as measured above Artesian Park. It seems safe to conclude that except during flood periods the difference in flow at the head of the canyon and the combined flow of the tributary streams as measured above Artesian Park is generally small and can be accounted for by transpiration and evaporation or by return flow by seepage from the shallow ground-water body above the clay confining bed. The stream-flow data as analyzed above seem to indicate that the natural discharge from the artesian reservolr by seepage beneath the clay confining bed or along its western and southern edges is not large.

The presence of high-level springs that is sue from the mountains at the west side of the valley shows that the ground water in the bedrock of the mountains stands at considerably higher altitudes than the ground water in the valley fill. Ground water in the bedrock of the mountains is therefore moving toward the valley, and this precludes any leakage of ground water from the valley through the mountains.

After consideration of all the factors bearing on the natural discharge from the artesian reservoir it is believed that such discharge is not in excess of about 5 second-feet.

Artificial discharge from the artesian reservoir occurs chiefly by the flow from artesian wells. Very little if any discharge occurs through pumped artesian wells, except the wells that are pumped with air at Artesian Park. Several small-diameter flowing wells are used for domestic supplies at a few farm homes, but as these wells are few and of small yield, the total amount so discharged is relatively small. It may be assumed to be 1 second-foot (about 700 acre-feet a year). Next to that of the municipal wells of Ogden at Artesian Park, the largest withdrawal by wells is made by the J. G. Read \& Bros. Co. Fish Hatchery (wells 86 to 95). The total flow from these wells was 688 gallons a 
minute (1.53 second-feet) on June 13, 1934. (See table of well records.) This discharge of course varies with the artesian pressure in the wells. The artesian pressure at the time of the measurement on June 13, was about an average of the pressures in these wells during the summer of 1933. (See pl. 38.) During September 1934 the pressure had decreased so that the flow of the wells was reduced by one-half or two-thirds.

The withdrawal from the artesian reservoir by the wells at Artesian Park constitutes the largest artificial discharge from the artesian reservoir. Of the 51 wells at Artesian Park, all but 3 are connected to a collecting system that supplies the city of Ogden with its manicipal water. During a part of each year some additional municipal water is obtained from Wheeler Creek, which enters the Ogden River just below Pine View Dam, and two smaller creeks that enter the river farther down the canyon. However, the flow from these creeks is very small during the sumer, and the artesian wells therefore constitute the main water supply for Ogden, a city with a population of about 40,000 . The rate of withdrawal from the wells at Artesian Park can be regulated by controlling works at the wells. About 19 of the wells are individualiy equipped with valves by which they can be closed or opened. Twenty-five wells are equipped with concrete catch basins around the well casings and can be made to flow into the catch basins over the tops of the casings, 4 or 5 feet above the surface. The catch basins drain by gravity into the collecting system. Wells flowing in this condition have, in local parlance, been "turned over." By means of valves, 22 of these 25 wells can be turned into the system at about 1 foot above the land surface, thereby increasing the natural flow. Wells flowing in this condition have, in local parlance, been "turned under." The 25 wells equipped with concrete catch basins and 3 other wells not so equipped can be pumped with compressed air furnished by five air compressors. The rate of withdrawal by the wells at Artesian Park ranged from about 13.3 to 20.5 second-feet during 1933 and from about 12.9 to 20.0 secondfeet during 1934. (See pl. 37.) The total discharge, as measured through a venturimeter, was about 11,500 acre-feet during the calendar year 1933 and about 11,800 acre-feet during the calendar year 1934. This is equivalent to an average yearly rate of withdrawal of 15.9 second-feet during 1933 and 16.3 second-feet during 1934. During July, August, and September, 1933, the withdrawal was 3,300 acre-feet, and during the corresponding period in 1934 the withdrawal was 3,420 acre-feet. 
Quantitative estimate.--The discharge from the wells at Artesian Park during the year ending September 30, 1934, was about 11,750 acrefeet, and the total withdrawal from other wells in the valley has been estimated at about 1,700 acre-feet. During that year the total quantity of surface water discharged from the valley was about 27,400 acre-feet. The only continuous flow through the stream channels in the valley during that year occurred through the North and Middle Forks from about March 5 to May 15. It is estimated from the hydrographs in plate 39 that of the total flow of these streams in this period about 16,800 acre-feet was direct surface run-off, the rest being derived from ground water that seeped into the streams in the lower part of the valley. Therefore, the total discharge of ground water from the valley during that year, exclusive of that lost by transpiration, evaporation, and underflow at the Pioneer Dam, amounted to about 24,000 acre-feet.

Plate 5 of a manuscript report on the Ogden Valley reclamation profect, by F. O. Larson, of the Bureau of Reclamation, dated August 1932, is a map of Ogden Valley on which the different types of land are show. One of the types is designated "pasture and water-logged." The areas so mapped are the lower parts of the valley, in which transpiration and evaporation are active during the growing season. These areas comprise about 2.5 square miles. If the yearly transpiration and evaporation is assumed to be 12 inches (a reasonable assumption) the annual loss by this means amounts to about 1,600 acre-feet ( 2.2 secondfeet).

The natural discharge from the artesian reservolr by seepage beneath the clay confining bed and by seepage along its western and southern edges is belleved not to exceed 5 second-feet. However, some of this water is returmed to the streams in the lower parts of the valley, and this amount has already been taken into account in the estimates of stream flow made above. Therefore, there remains only the part that percolates under the Pioneer Dam as underflow. From the stream measurements made in Ogden Canyon on September 20, 1934, 1t is believed that this underflow does not exceed about 3 second-feet (about 2,100 acre-feet a year).

From the measurements and estimates given above the total groundwater discharge during the year ending September 30, 1934, is computed to be about 27,700 acre-feet. 
Quality

The amount and character of dissolved mineral matter in the ground water of Ogden Valley are shown in a general way by some of the analyses made by E. W. Lohr, of the United States Geological Survey, which are given in the table at the end of the report. Elght samples of stream water were examined for comparison with the ground waters.

The analyses give no indication of the sanitary condition of the waters but indicate that the waters would be generally satisfactory for domestic use and for most industrial uses, so far as such uses are affected by the dissolved mineral matter. Some of the waters are harder than is desirable for certain purposes.

The fluoride content of samples from seven wells was determined by Margaret D. Foster, of the United States Geological Survey. The presence of fluoride in drinking water has been correlated with the occurrence of mottled enamel of the teeth of young children. Although no exact limit can be set, it has been reported by Smith that occurrences of mottled enamel have not been associated with the use of waters containing less than 1.0 part per million of fluoride. The range from 0.4 to 1.1 parts per million in the five samples of water from ogden valley in which fluoride was present suggests that these waters are not likely to be objectionable on account of their fluoride content.

\section{PINE VIEW DAM AND RESERVOIR}

General features

At the time of writing (1935) the United States Bureau of Reclamation is constructing an earth-fill dam on the Ogden River above the mouth of Wheeler Creek, a short distance below the head of Ogden Canyon. (See pl. 36, in pocket.) The water impounded above this dam $(41,000$ acre-feet) will be used for power and irrigation and possibly for other purposes. The water level in the reservoir when it is full will be 4,871 feet above mean sea level, United States Geological Survey datum. The shore Iine of the reservoir at its high stage is shown in plate 36 by a faint dotted line. The wells at Artesian Park are in the reservoir

13 Dean, H. T., Distribution of mottled teeth in the United States: U. S. Dept. 'Public Health Rept., vol. 40, no. 25, pp. 703-734, June 1933.

14/ Smith, H. V., The determination of fluoride in drinking water: Ind. and Eng. Chemistry, vo1. 7, p. 33, 1935. 
site and w1Il be covered with 30 to 40 feet of water when the reservoir is full. Provisions have been made whereby the flow from the wells will be plped through the reservoir and dam and into the conduit leading to ogden. The wells at Artesian Park will be equipped with an air-vent system to prevent air locking. Because the compressed-air pumps cannot be used after the reservoir is filled, the overflow points of the wells will be lowered about 4 or 5 feet, so as to increase the drawdown on the wells and thus to increase their potential discharge. Although the point of discharge below the dam will be lower than the overflow points of the wells, there will be no siphon action, because of the air-venting system.

Probable effects upon the artesian reservoir

The filling of the Pine View Reservoir will create a unique situation in that a large additional load, equal to the weight of water in the surface reservoir, will be superimposed on top of the clay confining bed. As the clay bed is essentially impervious, the amount of water that moves upward through it and thereby escapes from the artesian reservoir is, under existing conditions, practically negligible. When the PIne View Reservoir is filled the additional head of water will reverse the direction in which the water will tend to move through the confining bed, but even if the surface reservoir should remain full at all times, the amount of water entering the artesian reservoir, by seeping through the clay confining bed, would be very small. Actually the surface reservoir will be alternately filled and emptied, and its head of water will be greater than that of the artesian water only a part of the time. This alternation will normally occur once each year. The clay confining bed is believed to underlie the entire area indicated in plate 36 with no openings other than the pores between the clay particles through which water can move. The areal extent of the clay bed is greater than that of the surface reservoir. Consequently, if adequate precautions are taken to prevent leakage of the surface-reservoir water around the existing well casings, and if all abandoned wells are adequately plugged, there will be no appreciable leakage of surface water into the artesian reservolr.

When the surface reservoir is filled the additional load on the confining bed will cause the artesian water-bearing beds to be slightly compressed, thereby increasing the artesian pressure and the discharge 
from the artesian wells. Conversely, when the surface reservoir is emptied the artesian water-bearing beds will expand slightly, and the artesian pressure and discharge from the artesian wells will be decreased. If the surface reservoir were rapidly filled or emptied the rosulting change in rate of discharge of the artesian wells might be rather noticeable. However, the period during which the reservoir is filled or emptied will generally extend over a week or more, and it is doubtful whether a change in rate of discharge from the artesian wells will be apperent. Moreover, the riiling of the surface reservoir will generally occur during the period of spring run-off, and this will be at about the same time that ground-water recharge is taking place and the artesian pressure is increasing. Conversely, the artesian pressure will be decreasing at the same time that the surface reservoir is being emptied. Thus the tendency will be to increase the annual fluctuation of artesian pressure, but it will probably be difficult to differentiate between the two causes of the increased or decreased artesian pressure. It is theoretically probable that the compression of the artesian waterbearing beds resulting from the filling of the surface reservoir will to some extent decrease the permeability of the water-bearing sand and gravel and thus proportionately decrease the discharge from the artesian wells. It is believed, however, that the net change of rate of artesian discharge produced by the operation of the surface reservolr will not be of great practical importance.

\section{RHLATION OF ARTESIAN DISCHARGE TO STREAM FLOW}

During a considerable part of each year, chiefly in the spring, the stream water that enters Ogden Valley seeps into the stream channels. This water constitutes a large part of the ground-water recharge. Farther downstream water appears in the dry stream channels and continues to flow for the remainder of the stream courses. This water is groundwater run-off, or discharge from the ground-water body, either directly from the recharge area or from the shallow f1ll above the confining clay bed. During periods of the year when there is continuous flow through the streams--that is, when there are no dry stretches of stream channe1-the ground-water mun-off is probably as great as during periods when parts of the stream channels are dry, if not greater.

From figure 21 it may be seen that if the water table were to decline below the upper edge of the clay confining bed, none of the water 
seeping from the recharge area would reach the shallow water body above the clay bed. Under these conditions the artesian reservoir would be unwatered near its upper edge and this unwatered space would receive all the percolation from the recharge area until it became filled. Thereafter the shallow water body above the clay bed would again receive water from the recharge area. During the period from July 1933 to September 1934 frequent determination was made of the location of the points at which seepage began to appear in the channels of the three tributaries of the Ogden River. These points move upstream when groundwater levels rise and downstream when ground-water levels decline. During 1933 the lowest polnts at which seepage began on the Middle and South Forks were somewhat upstream from the edge of the clay confining bed, as shown by the dashed line in plate 36, but on the North Fork the lowest point was about half a mlle dowstream from the edge of the confining bed, as shown in plate 36. During 1934 the lowest points were about half a mlle downstream from the indicated edge of the clay bed on the Middle and South Forks and about a mile downstream on the North Fork. As previously stated, the upper edge of the clay confining bed is not absolutely definite, and its position is shown only approximately in plate 36. However, the points at which seepage began indicate that at the low stage in 1934 there was little or no discharge from the recharge area directly into the streams and probably not much into the shallow water body overlying the confining bed. The bottom of the clay confining bed in wells 81 and 82 is about 4,840 feet above sea level, whereas the water level in well. 82 at its lowest stage during 1934 (Oct. 5, see pl. 37) was about 4,866 feet above sea level, or about 26 feet above the bottom of the clay bed. The available evidence indicates that if there was any unwatering of the artesian reservoir during 1934 it was slight.

Before any artesian wells were drilled by the city of Ogden the water table throughout the valley doubtless rose as a result of recharge each spring and declined later in the season when the rate of discharge by seepage into the streams and by evaporation and transpiration exceeded the rate of recharge, but the water in the artesian part of the underground reservoir--the part confined under the clay bed--was essentially in dead storage. When the artesian wells were put into use the artesian part of the underground reservoir became functional. 
Thus the arilling of the artesian wells is to some extent analogous to the building of a surface reservoir.

The utilization of the artesian reservoir has inevitably resulted in a somewhat greater seasonal lowering of the water table than would otherwise have occurred. Therefore, it has also resulted in a diminution of the stream flow derived by seepage, the difference being least at the high stage of the water table, in late spring or early sumer, and greatest at the low stage, in late fall and early winter. The recharge during the winter and spring of any year has been increased over what it would otherwise have been, partly because of the lower level of the water table at the beginning of the recharge period and partly because of the withdrawal of water through the artesian wells during the period. In wet years the water table has probably been restored by the end of the recharge period nearly to the level it would have attained if there had been no artesian development, but in dry years the difference has doubtless been greater. During the sumer and fall of each year the decline of the water level has been expedited by the withdrawal through artesian wells, but with considerable lag caused by the elasticity of the water-bearing material in the artesian reservoir.

There is at present an essential balance between average annual discharge and average anmual recharge, as there doubtless was before any artesian wells were drilled, the withdrawal through artesian wells being compensated chiefly by increased recharge and decreased ground-water run-off. The increase in recharge occurs chiefly during the period of rising water levels in winter and spring; the decrease in ground-water run-off chiefly during the period of low water levels in fall and winter.

Unless there should in the future be heavy pumping from wells in the recharge area, the artesian water supply will be perennially adequate for at least the present rate of consumption. Moreover, somewhat greater utilization of the artesian reservoir would be possible by making heavier withdrawals at times when the water is neoded and inducing greater recharge at times of surplus water.

\section{WELL RECORDS}

Records of 146 wells in Ogden Valley are given in the table below. This table includes nearly all the wells in the valley at the time of this investigation. The locations of the wells are shown in plate 36 (in pocket). Of the 146 wells 70 are flowing artesian wells, 51 of 
Which are located at Artesian Park and furnish the municipal water supply for the city of Ogden. With the exception of the artesian wells, most of the wells shown in plate 36 are shallow dug wells. The average depth of 63 dug wells is about 21 feet, and their diameter ranges from about 3 to 5 feet. The depth of the flowing wells at Artesian Park ranges from 85 to 600 feet, and that of the 3 deepest wells is 475, 500, and 600 feet. The average depth of the other 48 wells is about 140 feet. The diameter of the wells at Artesian Park ranges from 2 to 12 inches, but most of them are 4 to 6 inches. Most of these artesian wells are cased throughout their depth, only a few of them having about the bottom 20-foot section perforated.

The only well logs available for Ogden Valley are those kept by the city of Ogden for the wells at Artesian Park and the carefully prepared logs of the 5 test wells put down during this investigation (wells 74 , 81, 82, 101, and 102). All the available well logs are shown in plate 40 (in pocket). 
Records of wells in Ogden

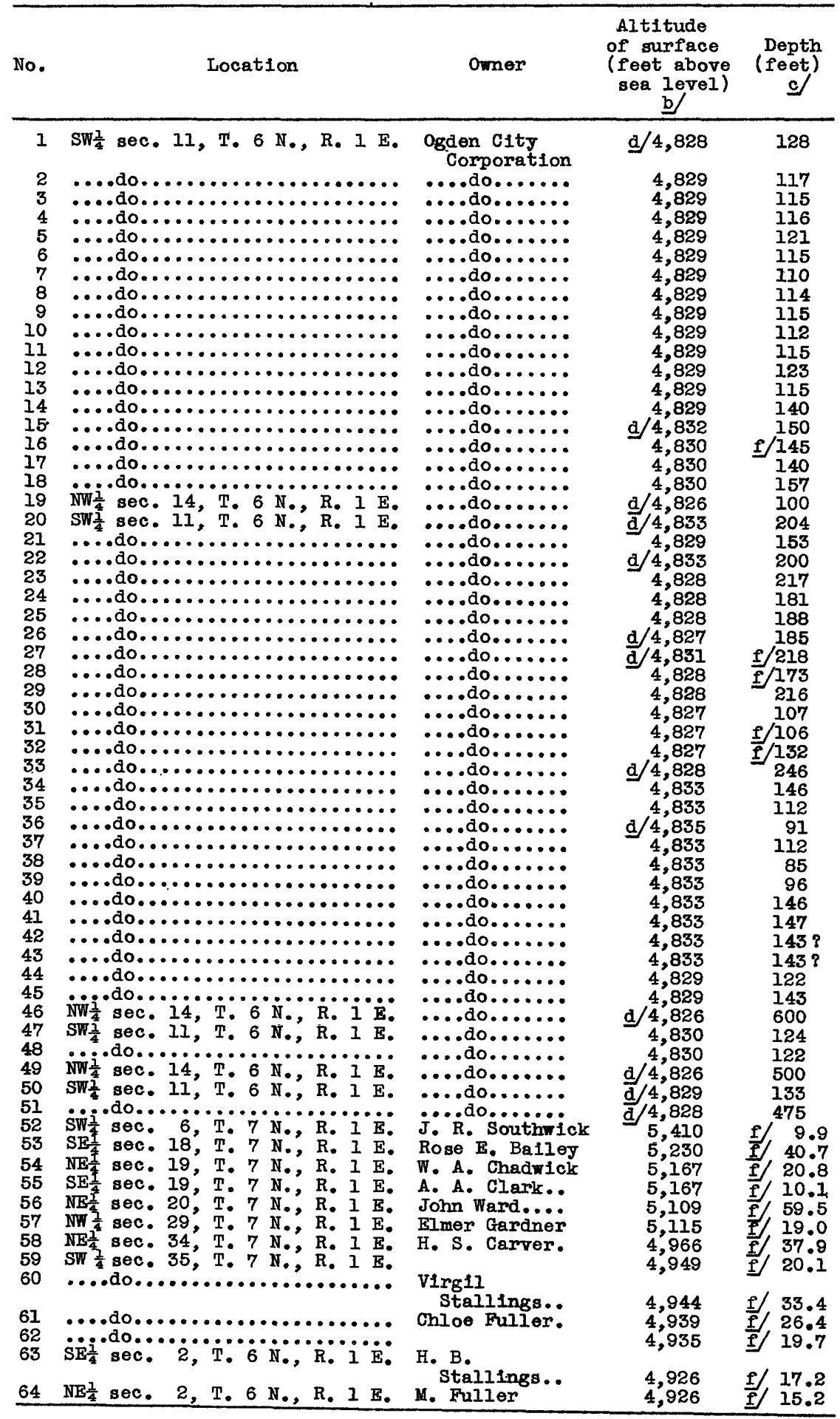


Valley, Weber County, Utaha/

\begin{tabular}{|c|c|c|c|}
\hline $\begin{array}{l}\text { Diameter } \\
\text { (Inches) }\end{array}$ & $\begin{array}{l}\text { Water level } \\
\text { (feet above } \\
\text { or below } \\
\text { surface) }\end{array}$ & $\begin{array}{l}\text { Date of } \\
\text { measure- } \\
\text { ment }\end{array}$ & Remarks \\
\hline
\end{tabular}

\begin{tabular}{|c|c|c|c|c|}
\hline 2 & +6.7 & Dec. 15,1933 & - & 1 \\
\hline & $\ddot{\cdots}$ & $\cdots \cdot \cdot$ & & $\begin{array}{l}2 \\
3\end{array}$ \\
\hline $\begin{array}{l}4 \\
4\end{array}$ & $\because \cdots$ & 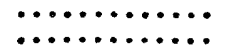 & $\cdots \cdots$ & $\begin{array}{l}3 \\
4\end{array}$ \\
\hline 4 & $\ldots$ & $\ldots \ldots$ & $\ldots \ldots$ & 5 \\
\hline $\begin{array}{l}4 \\
4\end{array}$ & $\cdots$ & $\because \cdots \cdots \cdots \cdots$ & $\cdots \cdots$ & 6 \\
\hline $\begin{array}{l}4 \\
4\end{array}$ & $\because \cdots$ & $\because \ldots \ldots \ldots \ldots$ & $\cdots \ldots \ldots$ & 7 \\
\hline 4 & +6.5 & $\ddot{\text { oct. }} \ddot{9}, \ddot{1} \ddot{\dot{s}} \dot{3}$ & $\cdots \cdots \cdots$ & 9 \\
\hline $\begin{array}{l}4 \\
4\end{array}$ & $\cdots \cdots$ & ........... & $\cdots \cdots \cdots$ & 10 \\
\hline $\begin{array}{l}4 \\
4\end{array}$ & $\cdots \cdots$ & $\cdots \cdots \cdots \cdots$ & $\cdots \cdots \cdots$ & 11 \\
\hline 4 & $\ddot{\cdots} \ddot{0}$ & $\because \cdots \cdots \cdots$ & $\cdots \cdots \cdots$ & $\begin{array}{l}12 \\
13\end{array}$ \\
\hline $\begin{array}{l}4 \\
6\end{array}$ & $\begin{array}{r}+5.5 \\
e /+5.0\end{array}$ & $\begin{array}{l}\text { oct. } 9, \ddot{9}, \dot{3 i 3} 3 \\
\text { Nov, } 11,1925\end{array}$ & $\because \cdots \cdots \cdots$ & 14 \\
\hline 6 & $\ldots$ & ............. & $\because \ldots \ldots \ldots$ & $\begin{array}{l}15 \\
16\end{array}$ \\
\hline 6 & $\cdots$ & …........ & $\ldots \ldots \ldots \ldots \ldots \ldots$ & 17 \\
\hline $\begin{array}{l}6 \\
6\end{array}$ & $\ddot{+4.8}$ & $\ddot{D e c} \ddot{i s}, \ddot{i g} \ddot{3} 3$ & $\cdots \cdots \cdots \cdots \cdots \cdots$ & 18 \\
\hline 6 & $e /+6.7$ & Nov. $11 ; 1925$ & $\because \ldots \ldots \ldots \ldots \ldots \cdots \cdots$ & $\begin{array}{l}19 \\
20\end{array}$ \\
\hline $\begin{array}{l}6 \\
6 \\
6\end{array}$ & $\begin{aligned} & \ddot{1} \cdot .9 \\
& +6.9 \\
& +2.2\end{aligned}$ & $\begin{array}{l}\text { Nov. } \dddot{i i}, \ddot{i g z s} 5 \\
\text { July } 26,1933\end{array}$ & $\because \cdots \cdots \cdots \cdots \cdots, \cdots \cdots \cdots, \cdots$ & 21 \\
\hline 6 & $\ddot{+6.0}$ & o…........... & 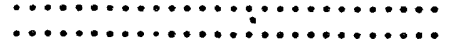 & $\begin{array}{l}23 \\
24\end{array}$ \\
\hline $\begin{array}{l}6 \\
6\end{array}$ & $\begin{array}{l}+6.5 \\
+7.9\end{array}$ & $\begin{array}{l}\text { Oct. } 9,1933 \\
\text { Dec. } 15,1933\end{array}$ & $\ldots \ldots \ldots$ & $\begin{array}{l}24 \\
25\end{array}$ \\
\hline $\begin{array}{l}6 \\
6\end{array}$ & $\theta /+7.9$ & $\begin{array}{l}\text { Dec. 15, } 1933 \\
\text { Nov. 11, } 1925\end{array}$ & $\because \ldots \ldots$ & 26 \\
\hline 6 & $\ddot{\cdots}$ & ............ & ${ }_{1} \ldots \ldots \ldots \ldots \ldots \ldots$ & 27 \\
\hline $\begin{array}{l}6 \\
6\end{array}$ & $\cdots$ & $\cdots \cdots \cdots \cdots \cdots$ & $\ldots \ldots \ldots \ldots \ldots \ldots \ldots \ldots \ldots$ & $\begin{array}{l}28 \\
29\end{array}$ \\
\hline 6 & $\ddot{\cdots}$ & $\because \ldots \ldots \ldots \ldots \cdots$ & $\cdots \cdots \cdots \cdots \cdots \cdots \cdots \cdots \cdots \cdots$ & 30 \\
\hline 6 & & $\because \ldots \cdots \cdots \cdots \cdots$ & $\ldots \ldots \cdots$ & 31 \\
\hline 6 & $e /+11.2$ & Nov. ii, i925 & $\ddot{\cdots \cdots \cdots}$ & $\begin{array}{l}32 \\
33\end{array}$ \\
\hline $\begin{array}{l}6 \\
8\end{array}$ & $\because \cdots$ & $\bullet \cdots \cdots \cdots \cdots$ & $\ldots \ldots \ldots \ldots \ldots \ldots$ & 34 \\
\hline 8 & $\ddot{+} \ddot{6} .6$ & $\ddot{D} \ddot{0} . \ddot{i s}, \ddot{i g} \ddot{z}$ & 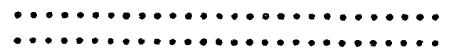 & 35 \\
\hline 6 & $\cdots \cdots$ & $\ldots \ldots \ldots \ldots$ & $\ldots \ldots \ldots \ldots$ & $\begin{array}{l}36 \\
37\end{array}$ \\
\hline $\begin{array}{l}6 \\
6\end{array}$ & 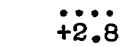 & Äpr. $\ddot{i z}, \ddot{i g} 3 \dot{3}$ & 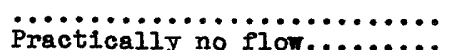 & 38 \\
\hline 6 & .... & $\ldots \ldots \ldots \ldots$ & 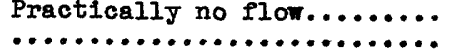 & 39 \\
\hline 6 & $\cdots$ & ............ & 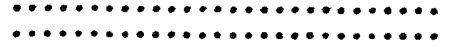 & 40 \\
\hline 6 & $\cdots \cdot$ & …......... & $\cdots \cdots \cdots \cdots$ & $\begin{array}{l}41 \\
42\end{array}$ \\
\hline $\begin{array}{l}6 \\
6\end{array}$ & $\cdots$ & $\cdots \cdots \cdots \cdots$ & $\ldots \ldots \ldots$ & 43 \\
\hline 6 & $\because \cdots$ & $\because \cdots \cdots \cdots \cdots$ & $\cdots$ & 44 \\
\hline 12 & +11.9 & $\ddot{D e c} \cdot \ddot{15}, \ddot{1933}$ & 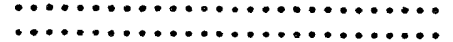 & 45 \\
\hline 6 & $\ddot{\cdots}$ & (........... & $\ldots \ldots \ldots \ldots$ & $\begin{array}{l}40 \\
47\end{array}$ \\
\hline 12 & $\cdots$ & $\ddot{\cdots} \cdots \cdots \cdots$ & ..... & 48 \\
\hline 6 & $\ddot{+7} \cdot \dot{5}$ & $\ddot{\text { Dec. }} 1 \overline{15}, \ddot{1933}$ & $\cdots$ & $\begin{array}{l}49 \\
50\end{array}$ \\
\hline $\begin{array}{l}12 \\
\text { Dug }\end{array}$ & $\begin{array}{r}+10.0 \\
-5.6\end{array}$ & $\begin{array}{l}\text { Dec. } 15,1933 \\
\text { Aug. } 18,1932\end{array}$ & $\ldots \ldots \ldots \ldots \ldots$ & 51 \\
\hline$\ldots$ & $\begin{array}{r}-0.0 \\
-38.4\end{array}$ & Aug. 18, 1932 & $\cdots$ & $\begin{array}{l}52 \\
53\end{array}$ \\
\hline $\begin{array}{l}\text { Dug } \\
\text { Dug }\end{array}$ & $\begin{array}{l}-17.6 \\
-6.2\end{array}$ & Aug. 18,1932 & $\cdots \ldots \ldots \ldots \ldots \ldots \ldots$ & 54 \\
\hline Dug & -54.8 & $\begin{array}{l}\text { Aug. } 18,1932 \\
\text { oct. } 12,1932\end{array}$ & $\cdots \cdots \cdots$ & 55 \\
\hline $\begin{array}{l}\text { Dug } \\
\text { Dug }\end{array}$ & -17.1 & Aug. 18,1932 & $\cdots \cdots \cdots \cdots$ & $\begin{array}{l}56 \\
57\end{array}$ \\
\hline Dug & $\begin{array}{l}-35.4 \\
-16.3\end{array}$ & $\begin{array}{l}\text { Aug. } 18,1932 \\
\text { Aug. } 18,1932\end{array}$ & $\ddot{\cdots}$ & 58 \\
\hline Dug & -25.9 & & & \\
\hline Dug & -18.2 & $\begin{array}{l}\text { Aug. 18, 1932 } \\
\text { Aug. } 18,1932\end{array}$ & & 60 \\
\hline Dug & -12.5 & Aug. 18, 1932 & $\because \cdots$ & $\begin{array}{l}61 \\
62\end{array}$ \\
\hline $\begin{array}{l}\text { Dug } \\
\text { Dug }\end{array}$ & $\begin{array}{r}-13.3 \\
-9.0\end{array}$ & $\begin{array}{l}\text { Aug. } 18,1932 \\
\text { Aug. } 18,1932\end{array}$ & $\cdots \cdots \cdots \cdots \cdots \cdots \cdots$ & $\begin{array}{l}63 \\
64\end{array}$ \\
\hline
\end{tabular}


Records of wells in Ogden

\begin{tabular}{|c|c|c|c|c|}
\hline No. & ilon & Owner & $\begin{array}{l}\text { Altitude } \\
\text { of surface } \\
\text { (feet above } \\
\text { sea level) } \\
\text { b] }\end{array}$ & $\begin{array}{l}\text { Depth } \\
\text { (feet) } \\
\text { c/ }\end{array}$ \\
\hline $\begin{array}{l}65 \\
66 \\
67 \\
68 \\
69 \\
70 \\
71 \\
72 \\
73\end{array}$ & 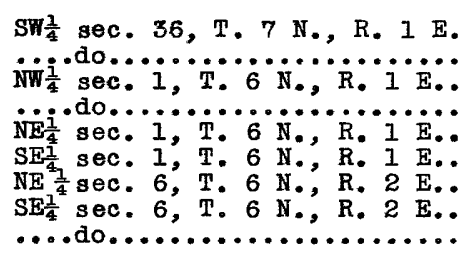 & 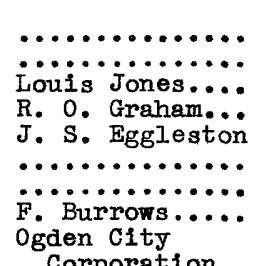 & $\begin{array}{l}4,926 \\
4,920 \\
4,922 \\
4,920 \\
4,935 \\
4,916 \\
5,008 \\
4,964\end{array}$ & $\begin{array}{l}f / 11.4 \\
f / 13.8 \\
f / 45.8 \\
f / 18.0 \\
f / 27.2 \\
f / 19 \\
f / 24.9 \\
f / 37\end{array}$ \\
\hline $\begin{array}{l}74 \\
75 \\
76 \\
77 \\
78 \\
79 \\
80\end{array}$ & 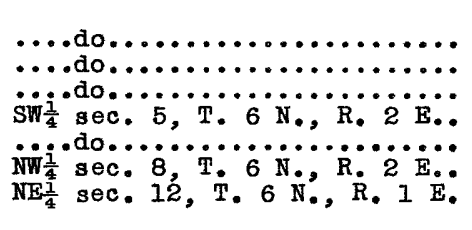 & 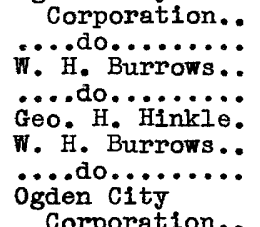 & $\begin{array}{r}\mathrm{d} / 4,950 \\
\mathrm{~d} / 4,951 \\
4,956 \\
4,958 \\
4,990 \\
4,970 \\
4,954\end{array}$ & $\begin{array}{c}14 \\
100 \\
\mathrm{f} / 16.4 \\
\mathrm{f} / 10.4 \\
\mathrm{~g} / 48 \\
\cdots \cdots\end{array}$ \\
\hline $\begin{array}{l}81 \\
82 \\
83\end{array}$ & 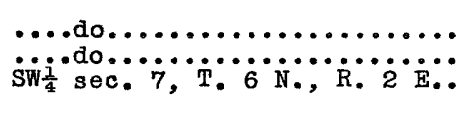 & 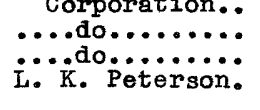 & $\begin{array}{r}\mathrm{d} / 4,879 \\
\mathrm{~d} / 4,880 \\
\mathrm{~d} / 4,880 \\
4,883\end{array}$ & $\begin{array}{r}4 \\
10 \\
108 \\
\mathrm{f} / 9.9\end{array}$ \\
\hline $\begin{array}{l}84 \\
85 \\
86\end{array}$ & 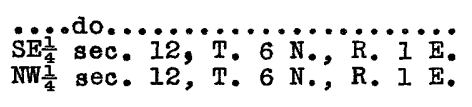 & 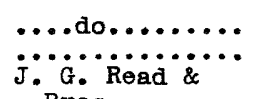 & $\begin{array}{l}4,884 \\
4,921\end{array}$ & $\begin{array}{l}\mathrm{f} / 10.6 \\
\mathrm{f} / 22.2\end{array}$ \\
\hline 87 & ....do. & 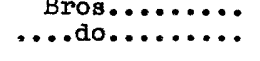 & $\begin{array}{l}4,852 \\
4,852\end{array}$ & $\cdots$ \\
\hline $\begin{array}{l}88 \\
89 \\
90 \\
91 \\
92 \\
93 \\
94 \\
95 \\
96 \\
97\end{array}$ & 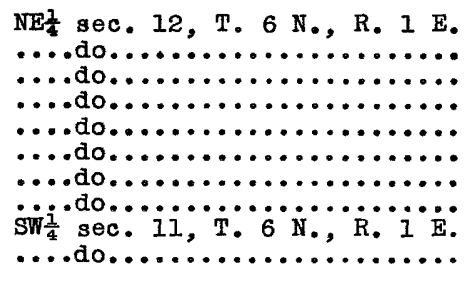 & 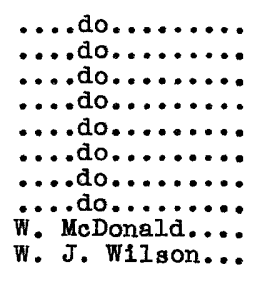 & $\begin{array}{l}4,856 \\
4,856 \\
4,856 \\
4,857 \\
4,857 \\
4,857 \\
4,857 \\
4,857 \\
4,848 \\
4,840\end{array}$ & $\begin{array}{r}\mathrm{f} / 43.5 \\
\ldots \ldots \\
\ldots \ldots \\
\mathrm{f} / 5 \ddot{2} . \dot{5} \\
\mathrm{f} / 49 \\
\mathrm{~h} / 24 \\
\mathrm{~g} / 125 \\
\mathrm{~g} / 65- \\
100-105\end{array}$ \\
\hline $\begin{array}{r}98 \\
99 \\
100\end{array}$ & & $\begin{array}{l}\text { F. O. Wilson.... } \\
\text { P. W. Burrows.. } \\
\text { Ogden City } \\
\text { Corporgtion.. }\end{array}$ & $\begin{array}{r}4,835 \\
4,839 \\
\mathrm{~d} / 4,832\end{array}$ & $\frac{\mathrm{g} / 80}{4}$ \\
\hline $\begin{array}{l}101 \\
102\end{array}$ & $\begin{array}{l}\ldots \text {.. do.... } \\
\ldots \ldots \text { do... } \\
\ldots \ldots \text { do... }\end{array}$ & 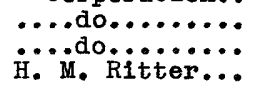 & $\begin{array}{r}\mathrm{d} / 4,833 \\
\mathrm{~d} / 4,832 \\
4,849\end{array}$ & $\begin{array}{r}68 \\
90 \\
\mathrm{~g} / 200\end{array}$ \\
\hline $\begin{array}{l}104 \\
105 \\
106 \\
107 \\
108 \\
109 \\
110 \\
111 \\
112 \\
113 \\
114 \\
115 \\
116 \\
117 \\
118 \\
119 \\
120 \\
121 \\
122\end{array}$ & 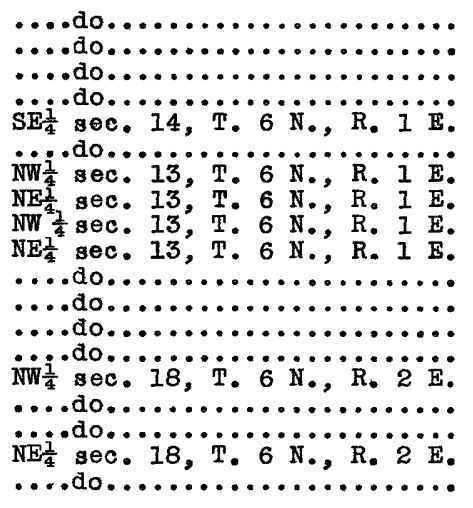 & 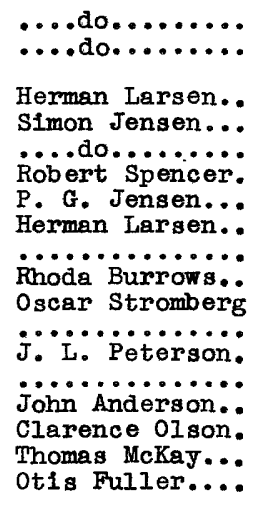 & $\begin{array}{l}4,835 \\
4,840 \\
4,835 \\
4,884 \\
4,853 \\
4,918 \\
4,896 \\
4,921 \\
4 ; 920 \\
4,922 \\
4,920 \\
4,917 \\
4,922 \\
4,872 \\
4,925 \\
4,927 \\
4,925 \\
4,931 \\
4,934\end{array}$ & $\begin{array}{l}\mathrm{g} / 1000 \\
\mathrm{f} / \ddot{15.9} \\
\mathrm{~g} / 75 \\
\mathrm{~g} / 132 \\
\mathrm{f} / 12.6 \\
\mathrm{f} / 24.3 \\
\mathrm{f} / 29.9 \\
\mathrm{f} / 22.5 \\
\mathrm{f} / 19.7 \\
\mathrm{f} / 21.2 \\
\mathrm{f} / 20.1 \\
\mathrm{~g} / 73 \\
\mathrm{f} / 19 \\
\mathrm{f} / 21 \\
\mathrm{f} / 17.8 \\
\mathrm{f} / 19.6 \\
\mathrm{f} / 21.8\end{array}$ \\
\hline
\end{tabular}


Valley, Weber County, Utah--continued

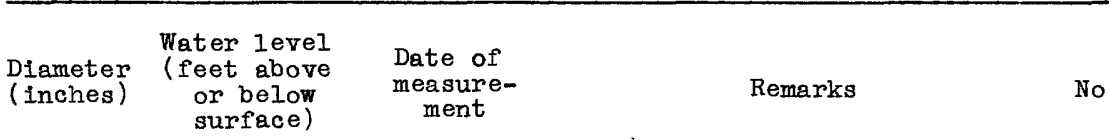

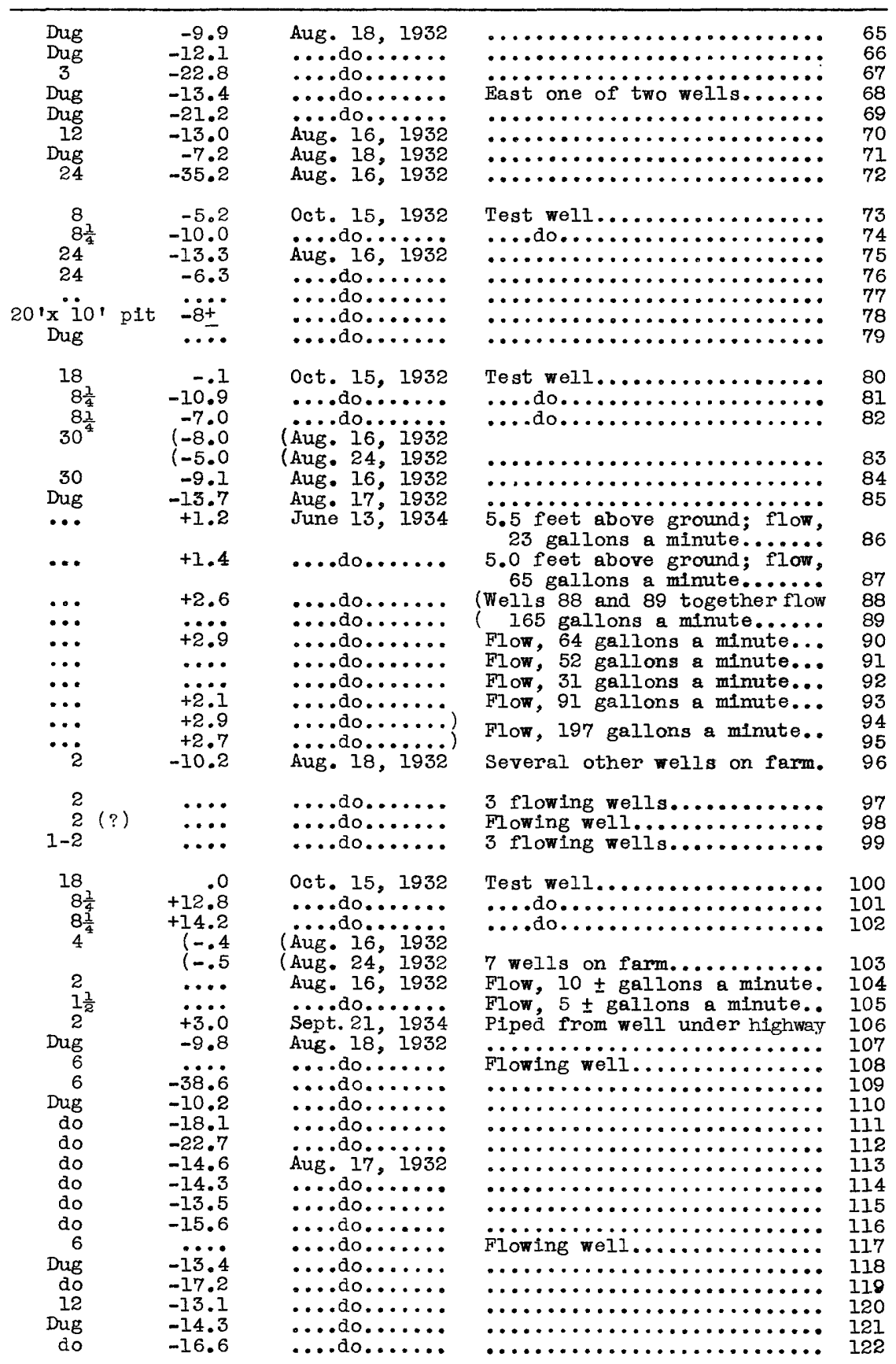


Records of wells in Ogden

\begin{tabular}{|c|c|c|c|c|}
\hline No. & Location & Owner & $\begin{array}{l}\text { Altitude } \\
\text { of surface } \\
\text { (feet above } \\
\text { sea level) } \\
\text { b/ }\end{array}$ & $\begin{array}{c}\text { Depth } \\
\text { (feet) } \\
\text { c }\end{array}$ \\
\hline $\begin{array}{l}123 \\
124 \\
125 \\
126 \\
127 \\
128 \\
129 \\
130 \\
131 \\
132 \\
133 \\
134 \\
135 \\
136 \\
137 \\
138 \\
139 \\
140 \\
141 \\
142 \\
143 \\
144 \\
145 \\
146\end{array}$ & 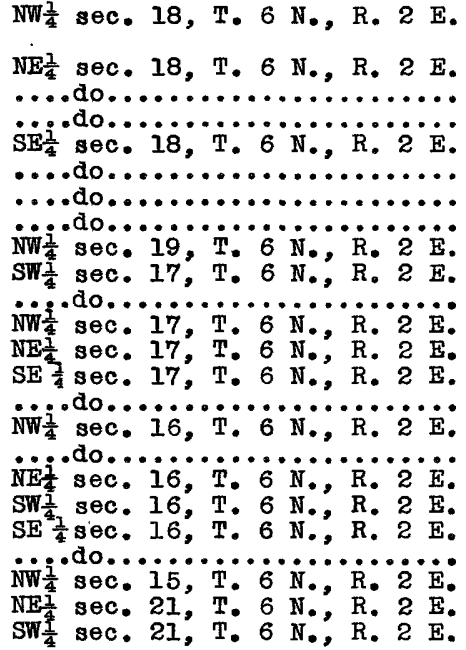 & 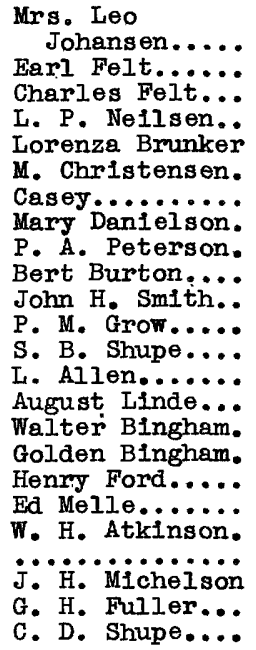 & $\begin{array}{l}4,931 \\
4,935 \\
4,933 \\
4,928 \\
4,934 \\
4,930 \\
4,936 \\
4,936 \\
4,908 \\
4,940 \\
4,946 \\
4,928 \\
4,957 \\
4,972 \\
4,977 \\
4,974 \\
4,990 \\
5,010 \\
4,992 \\
5,002 \\
5,027 \\
5,060 \\
5,005 \\
4,983\end{array}$ & 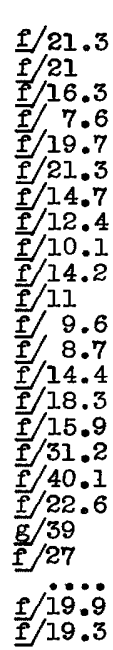 \\
\hline
\end{tabular}

a) According to the best information, all the wells owned by Ogden City Corporation were drilled with a solid-tool percussion drilling machine and the first drilling by the city of 0gden was during 0ctober 1914. Private wells were drilled either by a solid tool or a hydraulic drilling machine. Nearly all nonflowing, shallow wells were dug. The water-bearing materials in most wells are sand and gravel. (See pl. 40 for available well logs.)

b/ Altitudes were interpolated to the nearest foot from a topographic map having a 5-foot contour interval, except where noted.

c) According to the best information, most drilled wells were cased their entire depth. The depths of the wells of the Ogden City Corporation were obtained from the city engineer's records except where noted. 
Valley, Weber county, Utah--continued

\begin{tabular}{|c|c|c|c|c|}
\hline $\begin{array}{l}\text { Diameter } \\
\text { (Inches) }\end{array}$ & $\begin{array}{c}\text { Water level } \\
\text { (feet above } \\
\text { or below } \\
\text { surface) }\end{array}$ & $\begin{array}{l}\text { Date of } \\
\text { measure- } \\
\text { ment }\end{array}$ & Remarks & No. \\
\hline $\begin{array}{r}\text { Dug } \\
\text { do } \\
\text { do } \\
\text { do } \\
\text { do } \\
\text { do } \\
\text { do } \\
\text { do } \\
\text { do } \\
\text { do } \\
\text { do } \\
\text { do } \\
\text { do } \\
\text { do } \\
\text { do } \\
\text { do } \\
\text { do } \\
\text { 3o } \\
\text { Dug } \\
\text { do } \\
\text { do } \\
\text { do } \\
\text { do } \\
\text { do }\end{array}$ & $\begin{array}{l}-16.6 \\
-16.5 \\
-16.0 \\
-4.0 \\
-16.9 \\
-18.3 \\
-11.0 \\
-10.8 \\
-6.8 \\
-12.5 \\
\because . . . \\
-5.8 \\
-3.5 \\
-11.7 \\
-16.1 \\
-12.6 \\
-23.4 \\
-33.8 \\
-21.6 \\
\cdots \ldots .0 \\
\text { Dry } \\
-18.0 \\
-14.4\end{array}$ & 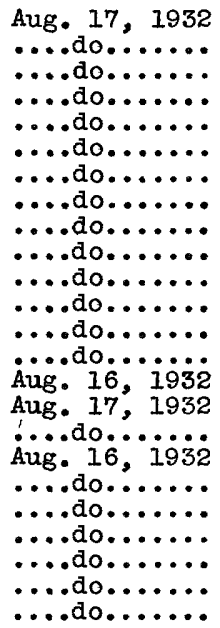 & 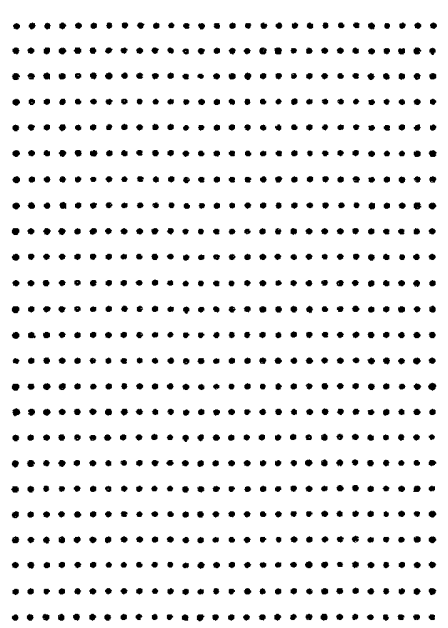 & $\begin{array}{l}123 \\
124 \\
125 \\
126 \\
127 \\
128 \\
129 \\
130 \\
131 \\
132 \\
133 \\
134 \\
135 \\
136 \\
137 \\
138 \\
139 \\
140 \\
141 \\
142 \\
143 \\
144 \\
145 \\
146\end{array}$ \\
\hline
\end{tabular}

d/ By instrumental levels.

- Measurements and altitudes obtained from the Utah state engineer's report of $a$ hydrographic survey of the Ogden River system during the Irrigation season of 1925 and from other data furnished by the State engineer.

f/ Measured.

g/ Reported.

h/ Partially filled with soft sediment. 
Records of water levels in wells in Ogden Valley, Weber County, Utah a

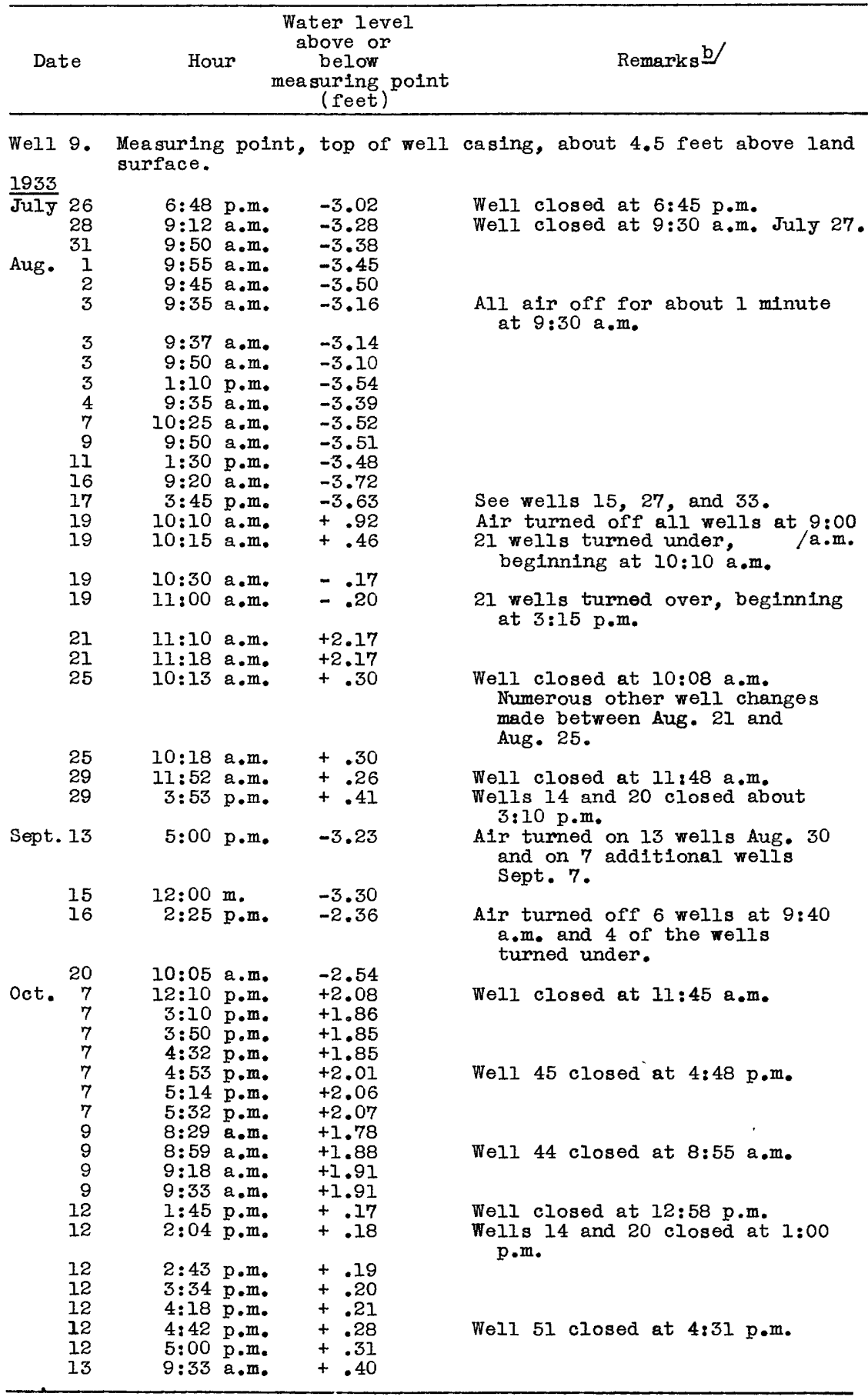


Records of water levels in wells in

Ogden Valley, Weber County, Utah--Contimued

Date Hour $\begin{gathered}\text { Water level } \\ \text { above or } \\ \text { below } \\ \text { measuring point } \\ \text { (feet) }\end{gathered}$

Well 14. Measuring point, top of well casing, about 4.5 feet above land surface.

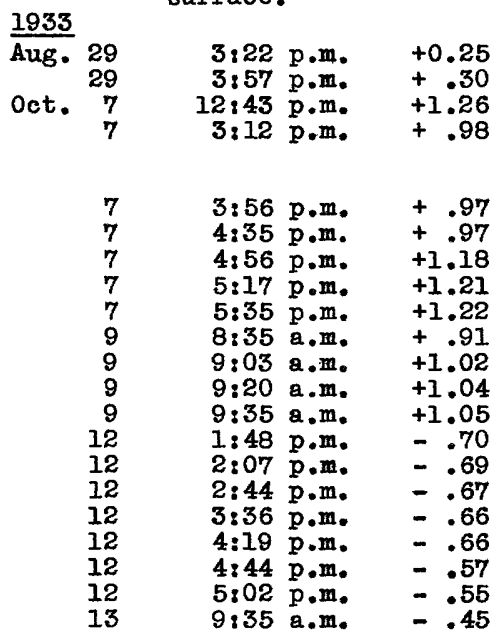

\author{
Well closed at 3:14 p.m. \\ Well closed at 12:18 p.m. \\ Wells 20 and 25 closed and wells \\ 30,31 , and 32 turned under \\ between $1: 10$ and $2: 25$ p.m.
}

We1.1 45 closed at 4:48 p.m.

Well 44 closed at 8:55 a.m.

Well 44 opened at $9: 47$ a.m.

Well 51 closed at 4:31 p.m.

We11 15. Measuring point, top of bell, altitude 4,837.26 feet, about 1925

\begin{tabular}{|c|c|c|c|c|}
\hline $\begin{array}{l}\overline{\text { July }} \\
\text { Aug. } \\
\text { Nov. } \\
1926\end{array}$ & $\begin{array}{r}18 \\
28 \\
6 \\
11\end{array}$ & $\begin{array}{r}12: 20 \\
4: 00 \\
5: 50 \\
12: 00\end{array}$ & $\begin{array}{l}p \cdot m . \\
p \cdot m . \\
p \cdot m . \\
m .\end{array}$ & $\begin{array}{l}c /-5.17 \\
c /-4.85 \\
c /-5.81 \\
c /+0.05\end{array}$ \\
\hline $\begin{array}{l}\text { Jan. } \\
\text { Apr. } \\
1928\end{array}$ & $\begin{array}{l}17 \\
22\end{array}$ & $\begin{array}{r}2: 00 \\
12: 45\end{array}$ & $\begin{array}{l}p \cdot m . \\
p \cdot m \text {. }\end{array}$ & $\begin{array}{l}-0.65 \\
-3.10\end{array}$ \\
\hline $\begin{array}{l}\text { Sept. } \\
\text { Oct. } \\
1933\end{array}$ & $\begin{array}{r}20 \\
4\end{array}$ & $\begin{array}{l}4: 10 \\
4: 15\end{array}$ & $\begin{array}{l}p \cdot m . \\
p \cdot m .\end{array}$ & $\begin{array}{l}c /-6.48 \\
c /-.15\end{array}$ \\
\hline Aug. & $\begin{array}{l}17 \\
17 \\
17 \\
17 \\
17 \\
17 \\
17\end{array}$ & $\begin{array}{l}2: 02 \\
2: 05 \\
2: 10 \\
2: 15 \\
2: 20 \\
2: 25 \\
2: 30\end{array}$ & $\begin{array}{l}p \cdot m . \\
p \cdot m . \\
p \cdot m . \\
p \cdot m . \\
p \cdot m . \\
p \cdot m . \\
p \cdot m .\end{array}$ & $\begin{array}{l}-4.64 \\
-4.62 \\
-4.60 \\
-4.59 \\
-4.58 \\
-4.57 \\
-4.56\end{array}$ \\
\hline
\end{tabular}

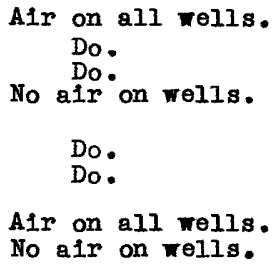

Well closed at 2:00 p.m.

Well 19. Measuring point, top of casing sleere, about 0.25 foct above 1933

\begin{tabular}{|c|c|c|c|}
\hline $\begin{array}{l}\overline{J u l y} 2 \\
\text { Aug. }\end{array}$ & $\begin{array}{r}25 \\
1 \\
2 \\
3 \\
4 \\
5 \\
6 \\
7 \\
8 \\
9 \\
10\end{array}$ & $\begin{array}{l}12: 50 \\
12: 00 \\
12: 00 \\
12: 00 \\
12: 00 \\
12: 00 \\
12: 00 \\
12: 00 \\
12: 00 \\
12: 00 \\
12: 00\end{array}$ & $\begin{array}{l}\mathrm{p} \cdot \mathrm{m} . \\
\mathrm{m} \cdot \\
\mathrm{m} . \\
\mathrm{m} \cdot \\
\mathrm{m} \cdot \\
\mathrm{m} \cdot \\
\mathrm{m} \cdot \\
\mathrm{m} \cdot \\
\mathrm{m} \cdot \\
\mathrm{m} \cdot \\
\mathrm{m} .\end{array}$ \\
\hline
\end{tabular}

By water-stage recorder.

Do.

Do.

Do.

Do.

Do.

Do.

Do.

Do.

Do.

Do. 
Records of water levels in wells in Ogden Valley, Weber County, Utah--Contimued

Date Hour $\begin{gathered}\text { Water level } \\ \text { above or } \\ \text { below } \\ \text { measuring point } \\ \text { (feet) }\end{gathered} \quad$ Remarks

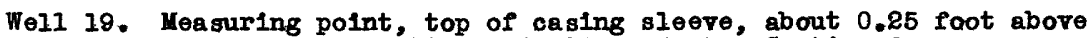
1933-Cont.

land surface, aititude $4,826.13$ feet.--Contimied.

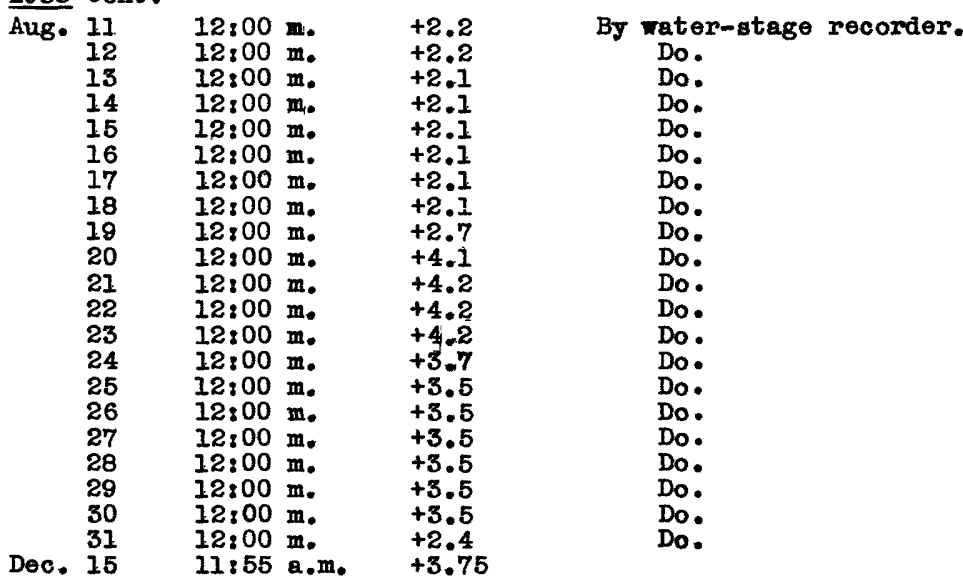

Well 20. Measuring point, top of bell, altitude $4,837.63$ feet, about 1925

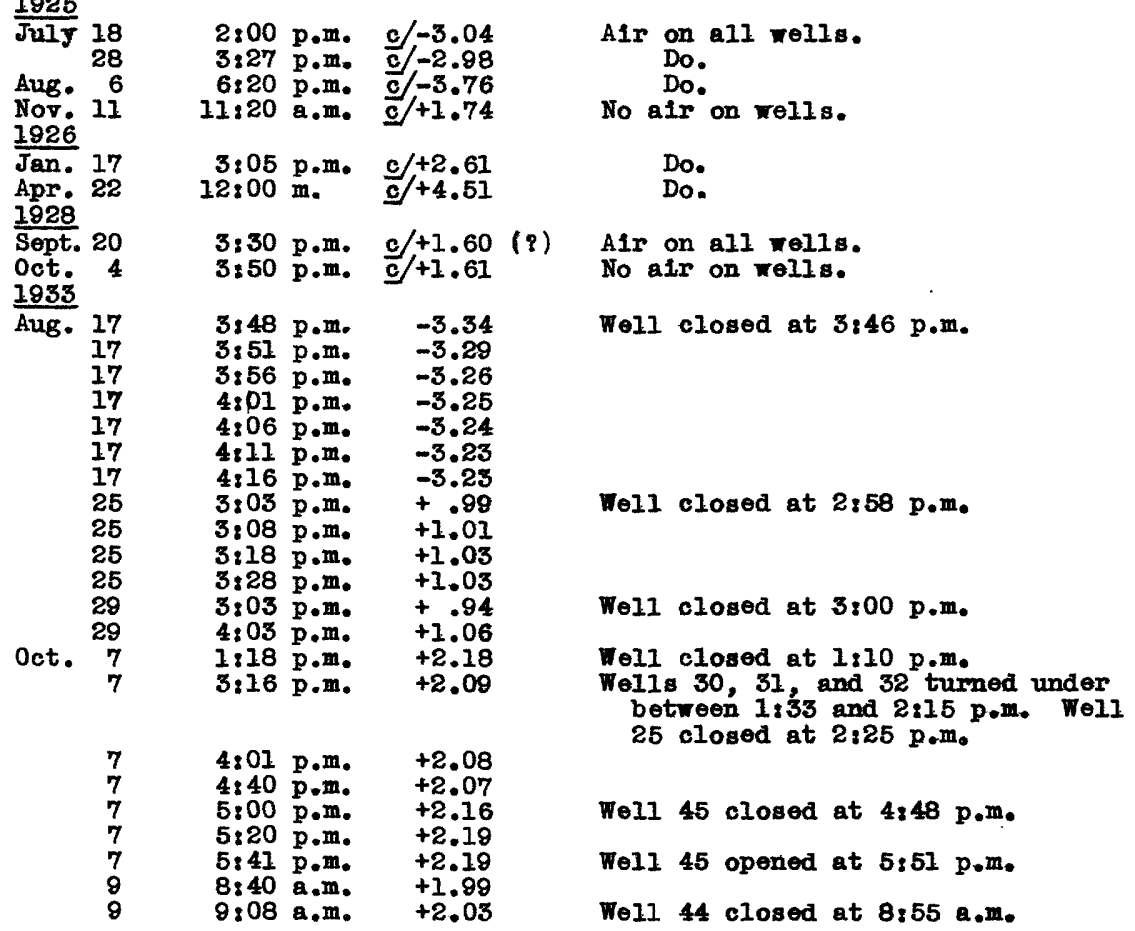


Records of water levels in reils in

Ogden Valley, Weber County, Utah--Continued

\begin{tabular}{|c|c|c|c|}
\hline Date & Hour & $\begin{array}{l}\text { Water level } \\
\text { above or } \\
\text { below } \\
\text { measuring point } \\
\text { (feet) }\end{array}$ & Remarks \\
\hline
\end{tabular}

We11 20. Heasuring point, top of be11, altitude 4,837.63 feet, about 1933-Cont.

5 feet above land surface.--Continued.

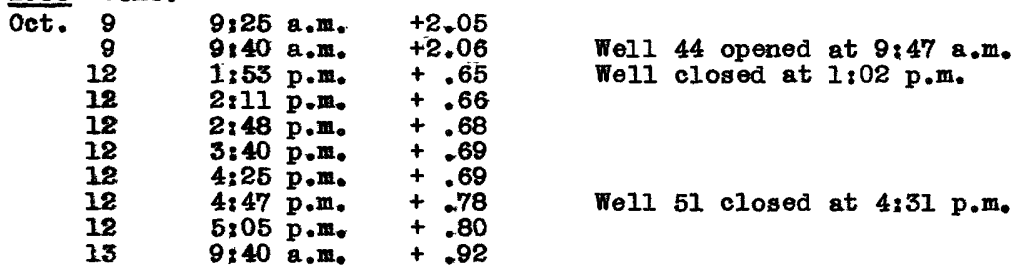

We11 22. Heasuring point, top of bel1, alt1tude, 4,837.73 feet, about

1925

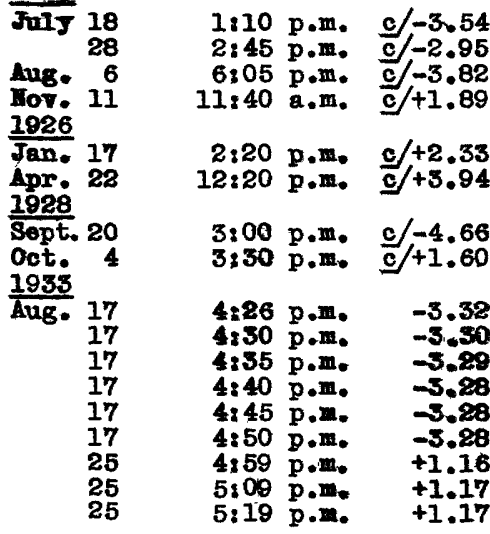

A1r on all wells.
Do.
Do.

No afr on we1ls.

$$
\begin{aligned}
& \text { Do. } \\
& \text { Do. }
\end{aligned}
$$

Air on a11 we11s.

To alr on mells.

Ne11 closed at 4,20 p.w.

We11 closed at $4: 49$ p.m.

Leaking a small amount.

Well 23. Measuring polnt, top of well casing, about 4.5 feet above land 1933

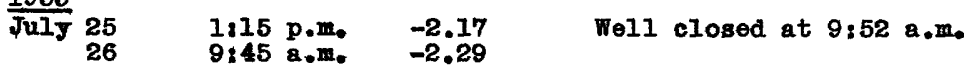

We11 25. Heasuring point, top of bell, about 5.5 feet abore land 2933 ourface.

$\begin{array}{rrrr}\text { Aug. } 29 & 3: 48 \text { p.m. } & -0.02 \\ \text { Det. } 7 & 2: 57 \text { p.m. } & +1.08 \\ 7 & 3: 24 \text { p.m. } & +1.06 \\ 7 & 4: 09 \text { p.m. } & +1.05 \\ 7 & 4: 43 \text { p.m. } & +1.04 \\ 7 & 5: 07 \text { p.m. } & +1.16 \\ 7 & 5: 26 \text { p.m. } & +1.17 \\ 7 & 5: 46 \text { p.m. } & +1.18 \\ 9 & 8: 45 \text { a.m. } & +.97 \\ 9 & 9: 13 \text { a.m. } & +1.03 \\ 9 & 9: 29 \text { a.m. } & +1.04 \\ 9 & 9: 43 \text { a.m. } & +1.05 \\ 12 & 12: 52 \text { p.m. } & -.46 \\ 12 & 1: 58 \text { p.m. } & -.28\end{array}$

Wells 9, 20, and 14 closed between $11: 48$ a.m. and $3: 14$ p.m. Foll closed at $2,25 \mathrm{p} . \mathrm{m}$.

Well 45 closed at $4: 48 \mathrm{p} . \mathrm{m}$.

Well 45 opened at $5: 51$ p.m.

We11 44 closed at 8.55 a.m.

We11 44 opened at 9,47 a.m.

Te11. 9,14 , and $20^{\circ}$ closed between $12: 58^{\prime}$ and $1,02 \mathrm{p} . \mathrm{m}$. 
Records of rater levels in wells in Ogden Valley, Weber County, Utah--Continued

Date Hour $\begin{gathered}\text { Water level } \\ \text { above or } \\ \text { below } \\ \text { measuring point } \\ \text { (feet) }\end{gathered}$ Remarks

Well 25. Measuring point, top of bell, about 5.5 feet above land 1933--Cont. surface.--Continued.

$\begin{array}{llll}\text { Oct. } 12 & 2: 40 \text { p.m. } & -.27 \\ 12 & 3: 30 \mathrm{p} \cdot \mathrm{m} . & -.25 \\ 12 & 4: 15 \mathrm{p} \cdot \mathrm{m} \cdot & -.25 \\ 12 & 4: 40 \mathrm{p} \cdot \mathrm{m} . & -.20 \\ 12 & 4: 56 \mathrm{p} \cdot \mathrm{m} . & -.17 & \\ 13 & 9: 29 \mathrm{a} \cdot \mathrm{m} . & -.05\end{array} \quad$ Well 51 closed at $4: 31$ p.m.

Well 26. Measuring point, top of 2 - by 6 -inch reducer, 2.5 feet above land surface, altitude $4,829.61$ feet.

1933

Dec. $15 \quad 2: 00$ p.m. $\quad+4.91$

Well 27. Measuring point, top of bell, 6 feet above land surface, $\underline{1925}$

\begin{tabular}{|c|c|c|c|c|}
\hline $\begin{array}{l}\text { July } \\
\text { Aug. } \\
\text { Nov. } \\
1926\end{array}$ & $\begin{array}{r}18 \\
28 \\
6 \\
11\end{array}$ & $\begin{array}{r}11: 45 \\
4: 15 \\
5: 35 \\
12: 15\end{array}$ & $\begin{array}{l}\mathrm{a} \cdot \mathrm{m} . \\
\mathrm{p} \cdot \mathrm{m} . \\
\mathrm{p} \cdot \mathrm{m} . \\
\mathrm{p} \cdot \mathrm{m} .\end{array}$ & $\begin{array}{l}c /-3.66 \\
\frac{c}{c} /-3.63 \\
\frac{c}{c} /+4.37 \\
c / 1.86\end{array}$ \\
\hline $\begin{array}{l}\text { Apr. } \\
1928\end{array}$ & 22 & $1: 00$ & p.m. & 01 \\
\hline $\begin{array}{l}\text { Sept } \\
1933\end{array}$ & 20 & $5: 20$ & $\mathrm{p} . \mathrm{m}$. & \\
\hline Aug. & $\begin{array}{l}17 \\
17 \\
17 \\
17 \\
17 \\
17 \\
17 \\
21 \\
21\end{array}$ & $\begin{array}{r}2: 36 \\
2: 38 \\
2: 43 \\
2: 48 \\
2: 53 \\
2: 58 \\
3: 03 \\
12: 43 \\
12: 53\end{array}$ & $\begin{array}{l}p \cdot m . \\
p \cdot m \cdot \\
p \cdot m . \\
p \cdot m . \\
p \cdot m . \\
p \cdot m \cdot \\
p \cdot m . \\
p \cdot m . \\
p \cdot m .\end{array}$ & $\begin{array}{l}-3.70 \\
-3.69 \\
-3.67 \\
-3.67 \\
-3.66 \\
-3.65 \\
-3.65 \\
+2.31 \\
+2.31\end{array}$ \\
\hline
\end{tabular}

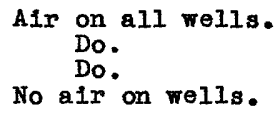
concrete floor of basin, which may or not have been occurring during previous measurements during 1933.

Well 33. Measuring point, top of bell, 8 feet above land surface,

1925

\begin{tabular}{|c|c|c|c|c|}
\hline$\frac{1}{\text { July }}$ & $\begin{array}{l}18 \\
28 \\
11\end{array}$ & $\begin{array}{r}11: 05 \\
5: 13 \\
12: 30\end{array}$ & $\begin{array}{l}\text { a.m. } \\
\text { p.m. } \\
\text { p.m. }\end{array}$ & $\begin{array}{l}c /-2.02 \\
\mathrm{c} /-1.78 \\
\mathrm{c} /+3.19\end{array}$ \\
\hline $\begin{array}{l}\frac{1926}{J a n} \\
1928\end{array}$ & 17 & $1: 15$ & p.m. & $\underline{\mathbf{c}}$ \\
\hline $\begin{array}{l}\text { Low } \\
\text { Sept. } \\
\text { oct. } \\
1933\end{array}$ & & $\begin{array}{l}4: 50 \\
5: 20\end{array}$ & $\begin{array}{l}\text { p.m. } \\
\text { p.m. }\end{array}$ & $\mathrm{c} /-$ \\
\hline Aug. & $\begin{array}{l}17 \\
17 \\
17 \\
17 \\
17 \\
17 \\
21 \\
21\end{array}$ & $\begin{array}{l}3: 10 \\
3: 15 \\
3: 20 \\
3: 25 \\
3: 30 \\
3: 35 \\
4: 49 \\
4: 55\end{array}$ & $\begin{array}{l}\text { p.m. } \\
\text { p.m. } \\
\text { p.m. } \\
\text { p.m. } \\
\text { p.m. } \\
\text { p.m. } \\
\text { p.m. } \\
\text { p.m. }\end{array}$ & $\begin{array}{l}-1.80 \\
-1.79\end{array}$ \\
\hline
\end{tabular}

Air on all wells. Do.

No air on wells.

Do.

Air on all wells.

No air on wells.

Well closed at 3:05 p.m. 
Records of water levels in wells in

Ogden Valley, Weber County, Utah--Continued

Date Hour $\begin{gathered}\text { Water level } \\ \text { above or } \\ \text { below } \\ \text { measuring point } \\ \text { (feet) }\end{gathered}$

Wel1 33. Measuring point, top of bel1, 8 feet above land surface, $1933--$ Cont. altitude, 4,836.36 feet.--Continued.

\begin{tabular}{|c|c|c|c|}
\hline Aug. & $\begin{array}{l}21 \\
21 \\
25 \\
25 \\
25 \\
25\end{array}$ & $\begin{aligned} 5: 0 \\
5: 1 \\
10: 3 \\
10: 4 \\
10: 5 \\
11: 0\end{aligned}$ & $\begin{array}{l}\mathrm{p} \cdot \mathrm{m} . \\
\mathrm{p} \cdot \mathrm{m} . \\
\mathrm{a} \cdot \mathrm{m} . \\
\mathrm{a} \cdot \mathrm{m} . \\
\mathrm{a} \cdot \mathrm{m} \\
\mathrm{a} \cdot \mathrm{m} .\end{array}$ \\
\hline
\end{tabular}

Well opened at $5: 25$ p.m.

Well closed at 10:30 a.m.

Wel1 36. Measuring point, top of " ${ }_{T} n, 1.0$ foot above land surface, 1933 Dec. $15 \quad 2: 10 \mathrm{p} \cdot \mathrm{m} . \quad+5.63$

Well 39. Measuring point, top of casing, 0.2 foot above land surface. 1933

\begin{tabular}{|c|c|c|c|c|}
\hline Apr. & $\begin{array}{r}5 \\
12 \\
19 \\
26\end{array}$ & $\begin{array}{l}10: 55 \\
12: 00 \\
11: 30 \\
11: 15\end{array}$ & $\begin{array}{l}a \cdot m . \\
m . \\
a \cdot m \text {. } \\
a, m .\end{array}$ & $\begin{array}{r}0.00 \\
+2.80 \\
+2.90 \\
+3.39\end{array}$ \\
\hline May & $\begin{array}{r}30 \\
10 \\
17 \\
24 \\
31\end{array}$ & $\begin{array}{r}12: 04 \\
11: 08 \\
11: 10 \\
10: 50 \\
4: 45\end{array}$ & $\begin{array}{l}\text { p.m. } \\
\text { a.m. } \\
\text { a.m. } \\
\text { a.m. }\end{array}$ & $\begin{array}{r}+4.48 \\
+4.76 \\
+5.42 \\
+5.92 \\
+5.92\end{array}$ \\
\hline June & $\begin{array}{r}7 \\
14 \\
21 \\
28\end{array}$ & $\begin{array}{l}11: 30 \\
12: 30 \\
11: 35 \\
12: 05\end{array}$ & $\begin{array}{l}\text { a.m. } \\
p \cdot m . \\
\text { a.m. } \\
p, m .\end{array}$ & $\begin{array}{r}+4.47 \\
+1.04 \\
+1.16 \\
+2.20\end{array}$ \\
\hline July & 5 & $11: 4$ & a.m. & +1 \\
\hline
\end{tabular}

Well 46. Measuring point, top of plate cover on "T", 1.6 feet above 1933 Dec. $15 \quad 1: 15$ p.m. $\quad+10.89$

Well 51. Measuring point, top of plate cover on "T", 0.5 foot above land surface, altitude, 4,827.97 feet.

1933

Dec. $15 \quad$ 1:00 p.m. $\quad+9.52$

a) For other well measurements see the table of well records and the figures showing the hydrographs of observation welis.

b/ When water-level measurements were made all connections to collecting systems were closed and all flow stopped. of the 48 flowing wells connected to the collecting system at Artesian Park, 22 can be made to flow elther over the top of the casing (turned over) or at a point about 4 feet lower (tumed under), and 28 of the 48 wells can be pumped with compressed air. For more data on valve and alr changes in the well field see plate 37.

c Measurements and altitudes were obtained from the Utah State eng1neer's report of a hydrographic survey of the Ogden River system during the irrigation season of 1925 and from other data furnished by the State engineer. Measurements of the water levels in wells during the State engineer's investigation were made after the well had been closed and all flow stopped for 30 minutes. 
Analyaes of water from ogien

(Parts per mslition.

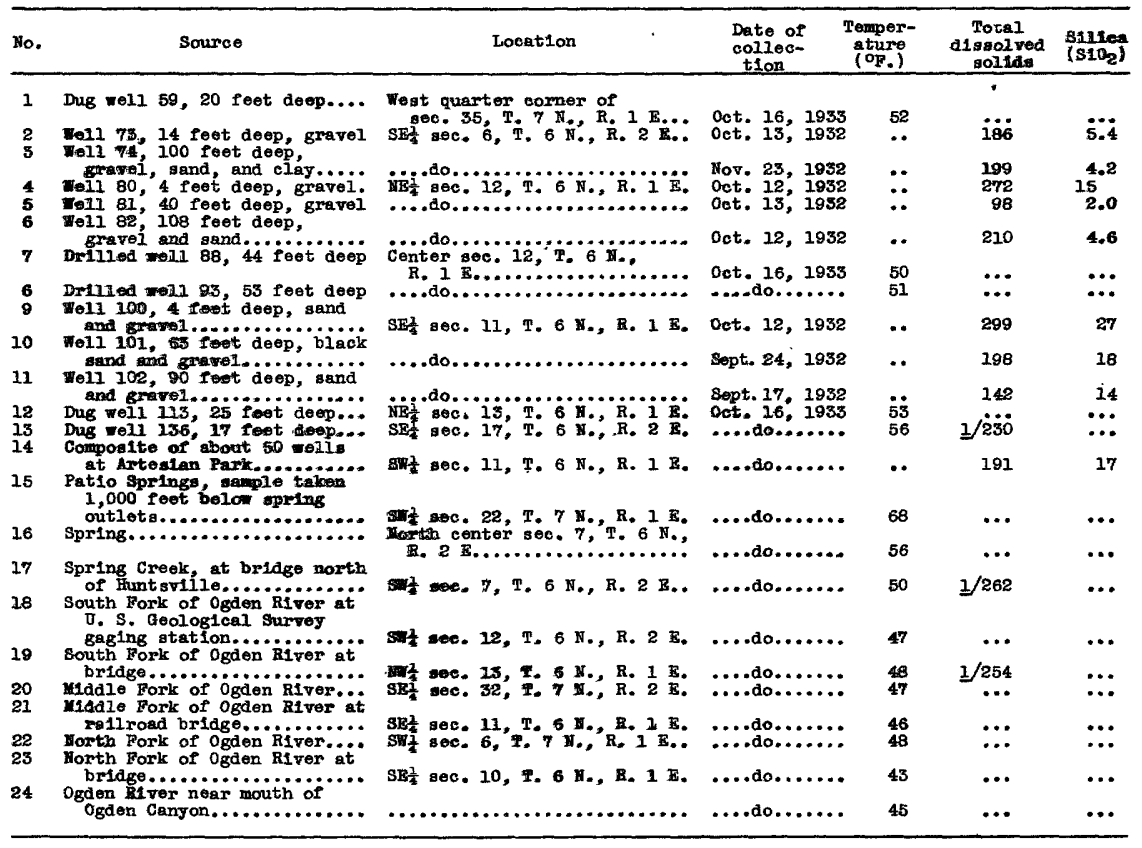

$1 /$ Sur of constituenta reported.

2f Less than 5 parts per rillion of aodium and potassium together. 
Valley, Wober County, Utah

B. W. Lohr, analyst)

\begin{tabular}{|c|c|c|c|c|c|c|c|c|c|c|c|}
\hline $\begin{array}{l}\text { Iron } \\
(\mathrm{Fe})\end{array}$ & $\begin{array}{c}\mathrm{Calclum} \\
(\mathrm{Ca})\end{array}$ & $\begin{array}{c}\text { Magnes 1um } \\
\left(\mathrm{Mg}_{\mathrm{g}}\right)\end{array}$ & Sodium & $\begin{array}{l}\text { Potassium } \\
\text { (K) }\end{array}$ & $\begin{array}{l}\text { Bicar- } \\
\text { bonate } \\
\left(\mathrm{HCO}_{3}\right)\end{array}$ & $\mathrm{sulphate}_{\left(\mathrm{SO}_{4}\right)}$ & $\begin{array}{c}\text { Chloride } \\
(\mathrm{Cl})\end{array}$ & $\begin{array}{l}\text { Flúportede } \\
\text { (F) }\end{array}$ & $\begin{array}{c}\text { Fitrate } \\
\left(\mathrm{NO}_{3}\right)\end{array}$ & $\begin{array}{l}\text { Totel } \\
\text { hardness } \\
\text { as } \mathrm{CaCO}_{3}\end{array}$ & Ho. \\
\hline 0.002 & $\ddot{4} \dot{2}$ & i3 & $\ddot{8} \cdot \overrightarrow{3}$ & $\ddot{3} .0$ & $\begin{array}{l}111 \\
178\end{array}$ & $\begin{array}{l}15 \\
14\end{array}$ & ${ }_{8.0}^{12}$ & $\ddot{0}$ & 29 & $\frac{135}{158}$ & $\frac{1}{2}$ \\
\hline $\begin{array}{l}.46 \\
.05 \\
.03\end{array}$ & $\begin{array}{l}41 \\
68 \\
22\end{array}$ & $\begin{array}{l}12 \\
20 \\
6.8\end{array}$ & $\begin{array}{l}20 \\
6.5 \\
6.0\end{array}$ & $\begin{array}{l}1.7 \\
3.2 \\
2.6\end{array}$ & $\begin{array}{r}194 \\
302 \\
96\end{array}$ & $\begin{array}{l}16 \\
12 \\
10\end{array}$ & $\begin{array}{r}17 \\
8.8 \\
5.5\end{array}$ & $\ddot{0}$ & $\begin{array}{l}0 \\
0 \\
2,4\end{array}$ & $\begin{array}{r}152 \\
252 \\
83\end{array}$ & $\begin{array}{l}5 \\
4 \\
5\end{array}$ \\
\hline .01 & 13 & 9.5 & 47 & 4.3 & 64 & 32 & 61 & .4 & 0 & 71 & 6 \\
\hline$\ddot{\cdots}$ & $\ddot{0}$ & $\ddot{0}$ & $\cdots$ & $\ldots$ & $\begin{array}{l}116 \\
164\end{array}$ & $\begin{array}{r}8 \\
10\end{array}$ & $\begin{array}{l}10 \\
16\end{array}$ & $\cdots$ & 13.2 & $\begin{array}{l}102 \\
155\end{array}$ & $\stackrel{7}{8}$ \\
\hline .02 & 73 & 17 & 7.2 & 6.0 & 286 & 17 & 12 & .8 & 6.0 & 252 & 9 \\
\hline .04 & 47 & 10 & 14 & 2.0 & 197 & 2.5 & 22 & 1.1 & 0 & 158 & 10 \\
\hline $\begin{array}{l}.02 \\
\cdots \ldots\end{array}$ & $\begin{array}{l}\text { so } \\
64\end{array}$ & i8 & 11 & 2... & $\begin{array}{l}131 \\
398 \\
259\end{array}$ & $\begin{array}{c}8.7 \\
12 \\
9\end{array}$ & $\begin{array}{l}10 \\
10 \\
7.0\end{array}$ & $\therefore 6$ & $\begin{array}{c}\frac{1}{2.3} \\
4.1\end{array}$ & $\begin{array}{l}105 \\
368 \\
234\end{array}$ & $\begin{array}{l}11 \\
12 \\
13\end{array}$ \\
\hline .01 & 43 & 11 & 9.8 & 1.5 & 173 & 12 & 10 & $\cdots$ & 6.2 & 153 & 14 \\
\hline$\cdots$ & . & . & $\cdots$ & ... & 73 & 8 & 10 & $\ldots$ & .25 & 58 & 15 \\
\hline$\cdots$ & $\ldots$ & . & $\cdots$ & $\ldots$ & 224 & 9 & 5.0 & $\ldots$ & 15 & 204 & 16 \\
\hline$\cdots$ & 72 & 20 & & $\underline{2} /$ & 286 & 12 & 11 & $\cdots$ & 3.9 & 262 & 17 \\
\hline$\cdots$ & . & $\ldots$ & $\cdots$ & $\cdots$ & 242 & 10 & 6.0 & $\ldots$ & .65 & 192 & 18 \\
\hline$\ddot{\cdots}$ & $\begin{array}{l}72 \\
\cdots\end{array}$ & $\begin{array}{l}19 \\
\cdots\end{array}$ & $\cdots$ & $\cdots$ & $\begin{array}{l}289 \\
166\end{array}$ & $\begin{array}{l}8 \\
6\end{array}$ & $\begin{array}{l}8.0 \\
8.0\end{array}$ & $\ddot{\cdots}$ & $\begin{array}{r}1.3 \\
.0\end{array}$ & $\begin{array}{l}258 \\
135\end{array}$ & $\begin{array}{l}19 \\
20\end{array}$ \\
\hline$\ddot{\cdots}$ & 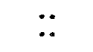 & $\ddot{0}$ & $\ddot{\cdots}$ & $\ddot{\cdots}$ & $\begin{array}{r}187 \\
71\end{array}$ & $\begin{array}{l}10 \\
20\end{array}$ & $\begin{array}{l}6.0 \\
3.0\end{array}$ & $\cdots$ & $\begin{array}{r}2.2 \\
.20\end{array}$ & $\begin{array}{r}159 \\
78\end{array}$ & $\begin{array}{l}21 \\
22\end{array}$ \\
\hline$\cdots$ & $\cdots$ & $\cdots$ & $\cdots$ & $\cdots$ & 175 & 13 & 5.0 & $\ldots$ & 2.1 & 156 & 23 \\
\hline$\cdots$ & $\cdots$ & . & $\cdots$ & $\ldots$ & $22 \theta$ & 20 & 14 & $\ldots$ & .53 & 210 & 24 \\
\hline
\end{tabular}

